\title{
Indium-based and iodine-based labeling of HPMA copolymer-epirubicin conjugates: Impact of structure on the in vivo fate
}

\author{
Libin Zhang ${ }^{\mathrm{a}}$, Rui Zhang ${ }^{\mathrm{a}}$, Jiyuan Yang ${ }^{\mathrm{a}}$, Jiawei Wang ${ }^{\mathrm{a}}$, Jindřich Kopeček ${ }^{\mathrm{a}, \mathrm{b}, *}$ \\ ${ }^{a}$ Department of Pharmaceutics and Pharmaceutical Chemistry/CCCD, University of Utah, Salt Lake City, \\ UT 84112, USA, ${ }^{b}$ Department of Bioengineering, University of Utah, Salt Lake City, UT 84112, USA
}

"Corresponding author: Jindřich Kopeček, Center for Controlled Chemical Delivery (CCCD), 20 S 2030 E, BPRB 205B, University of Utah, Salt Lake City, UT 84112-9452, USA. Phone: (801) 581-7211; Fax: (801) 581-7848.

E-mail address: jindrich.kopecek@utah.edu (J. Kopeček) 


\section{ABSTRACT}

Recently, we developed $2^{\text {nd }}$ generation backbone degradable $\mathrm{N}$-(2-hydroxypropyl)methacrylamide (HPMA) copolymer-drug conjugates which contain enzymatically cleavable sequences (GFLG) in both polymeric backbone and side-chains. This design allows using polymeric carriers with molecular weights above renal threshold without impairing their biocompatibility, thereby leading to significant improvement in therapeutic efficacy. For example, $2^{\text {nd }}$ generation HPMA copolymer-epirubicin (EPI) conjugates (2P-EPI) demonstrated complete tumor regression in the treatment of mice bearing ovarian carcinoma. To obtain a better understanding of the in vivo fate of this system, we developed a duallabeling strategy to simultaneously investigate the pharmacokinetics and biodistribution of the polymer carrier and drug EPI. First, we synthesized two different types of dual-radiolabeled conjugates, including 1) ${ }^{111} \mathrm{In}-2 \mathrm{P}-\mathrm{EPI}-{ }^{125} \mathrm{I}$ (polymeric carrier $2 \mathrm{P}$ was radiolabeled with ${ }^{111} \mathrm{In}$ and drug EPI with ${ }^{125} \mathrm{I}$ ), and 2) ${ }^{125} \mathrm{I}-2 \mathrm{P}-\mathrm{EPI}-{ }^{111} \mathrm{In}$ (polymeric carrier $2 \mathrm{P}$ was radiolabeled with ${ }^{125} \mathrm{I}$ and drug EPI with ${ }^{111} \mathrm{In}$ ). Then, we compared the pharmacokinetics and biodistribution of these two dual-labeled conjugates in female nude mice bearing A2780 human ovarian carcinoma. There was no significant difference in the blood circulation between polymeric carrier and payload; the carriers $\left({ }^{111} \mathrm{In}-2 \mathrm{P}\right.$ and $\left.{ }^{125} \mathrm{I}-2 \mathrm{P}\right)$ showed similar retention of radioactivity in both tumor and major organs. However, compared to ${ }^{111}$ In-labeled payload EPI, ${ }^{125}$-labeled EPI showed lower radioactivity in normal organs and tumor at $48 \mathrm{~h}$ and $144 \mathrm{~h}$ after intravenous administration of conjugates. This may be due to different drug release rates resulting from steric hindrance to the formation of enzyme-substrate complex as indicated by cleavage experiments with lysosomal enzymes (Tritosomes). A slower release rate of EPI(DTPA) ${ }^{111}$ In than EPI(Tyr) ${ }^{125}$ was observed. It may be also due to in vivo catabolism and subsequent iodine loss as literature reported. Nevertheless, tumor-to-tissue uptake ratios of both radionuclides were comparable, indicating that drug-labeling strategy does not affect the tumor targeting ability of HPMA copolymer conjugates.

Key words : N-(2-hydroxypropyl)methacrylamide (HPMA); epirubicin; polymer-drug conjugates, dualradiolabeling; pharmacokinetics and biodistribution. 


\section{INTRODUCTION}

Conjugation of anticancer drugs to water-soluble polymers offers a possibility to improve their solubility, decrease adverse effects, modify pharmacokinetics, favorably change their biodistribution, and improve therapeutic efficacy by enhanced permeability and retention (EPR) effect [1-4]. Numerous synthetic polymers have been used such as poly(ethylene glycol) (PEG) [5,6], [N-(2hydroxypropyl)methacrylamide] (HPMA) copolymers [7-11], poly(amino acids) [12], polyoxazoline [13], poly(malic acid) [14], etc. Among the various polymeric carriers, the most commonly used is PEG, which has been approved by FDA for clinical application and is commercial available in a wide range of molar masses, end-functionalities as well as different architectures. However, the use of PEG can be problematic in some instances, with recent results indicating PEG-containing therapeutics can elicit complement activation, rapid clearance after repeated injections, and may suffer from peroxidation $[15,16]$. Moreover, the inability to effectively functionalize the polyether backbone mitigates the utility of many PEG drug delivery systems [17]. HPMA copolymers have comparable biocompatibility and advantages over PEG on non-immunogenicity and established bioconjugation strategies. Its favorable properties have been validated by diverse preclinical and clinical studies [18-22]. Recently, higher molecular weight $(\mathrm{Mw})$ biodegradable HPMA copolymer-drug conjugates have been designed with enzymatically degradable tetrapeptide sequences (GFLG) in both polymer backbone and side chains to prolong plasma circulation and enhance tumor accumulation while preserving biocompatibility [23-28].

The knowledge of the pharmacokinetics and biodistribution of macromolecular therapeutics is a prerequisite for the understanding of the mechanism of their action and ultimate translation into clinical use. The fate of HPMA copolymers after administration to animals has been intensively studied. Initially, drug concentration in various organs was determined by direct extraction of drug from lyophilized tissue samples followed by HPLC analysis or fluorescence assay [29,30]. This approach needs large groups of animals and tedious work; it was replaced by radiolabeling strategy, which has high sensitivity and was widely applied in preclinical studies and clinical investigations [31,32]. Among different radionuclides single-step iodination $\left({ }^{124} \mathrm{I},{ }^{125} \mathrm{I}\right.$ and $\left.{ }^{131} \mathrm{I}\right)$ and two-step radiometal labeling $\left({ }^{90} \mathrm{Y},{ }^{111} \mathrm{In}\right.$ and ${ }^{177} \mathrm{Lu}$, etc.) are often performed. Iodination has been frequently used due to low cost and simple radiochemistry. For example, it was reported that radioiodination of drugs (daunomycin and doxorubicin) was achieved by mixing drug (or conjugate) solution with iodide in an iodogen reaction vial under ambient condition for a few minutes [33,34]. In the majority cases, however, tyrosine moiety was typically incorporated into polymer carrier via copolymerization followed by iodine labeling [35-41]. In these cases, the radioactive signals were correlated to the polymer carrier rather than drug. To examine the circulation and accumulation of real drug molecules, ${ }^{14} \mathrm{C}$-labeled drug might be an option. Nevertheless, such isotope-labeled drugs are expensive; the synthesis of conjugates will be complicated because ${ }^{14} \mathrm{C}$ has a long half-life and will cause large level of irradiation. Recently, duallabeling strategies have been developed in which one probe aims to track the polymer carrier, while the other one monitor the fate of drug (modified or model drug) [26,42-43]. For example, dual-fluorescent conjugates were studied using Fluorescence resonance energy transfer (FRET) as a tool to track chain scission of the conjugates and drug release from the carrier [28], or using noninvasive multispectral optical imaging to real time monitor the distribution and tumor accumulation of polymer carrier and a cleavable model drug [44]. Recently we designed dual-isotope-labeled $2^{\text {nd }}$ generation HPMA 
copolymer-drug model conjugate, whose HPMA copolymer backbone was labeled with ${ }^{125}$, whereas ${ }^{111}$ In-DTPA complex was bound at GFLG side-chain termini and served as the drug model [26].

We have reported the pharmacokinetics and therapeutic efficacy of $2^{\text {nd }}$ generation diblock HPMA copolymer-epirubicin (EPI) conjugates (2P-EPI) in the treatment of experimental ovarian cancer [28]. Notably, treatment with $2 \mathrm{P}$-EPI resulted in complete tumor remission and long-term inhibition of tumorigenesis ( $>100$ days), whereas the tumor recurrence was observed in mice treated with the $1^{\text {st }}$ generation HPMA copolymer-EPI conjugate (P-EPI, with $\mathrm{Mw}<50 \mathrm{kDa}$ ). To demonstrate the different pharmacologies between these two generations of conjugates, we designed and synthesized a series of dual radiolabeled HPMA copolymer-EPI conjugates in which ${ }^{125} \mathrm{I}$ and ${ }^{111}$ In were used to label polymer carrier and drug (EPI), respectively, or vice versa. This paper is devoted to the study of pharmacokinetics and biodistribution of $2^{\text {nd }}$ generation HPMA copolymer-EPI conjugates in nude mice. In one approach, we labeled the polymer carrier with ${ }^{125} \mathrm{I}$ and used DTPA- ${ }^{111}$ In to modify the EPI structure. In the second design, we used DTPA- ${ }^{111}$ In to label the polymer carrier and ${ }^{125}$ I for drug modification. The issues we addressed are: A) How does modification of the conjugate structure influence its fate? Is there a difference between the two labeling designs? B) How does the modification of drug structure impact the formation of the enzyme-substrate complex, rate of enzymatic drug release and the biodistribution of the drug? C) How does the data obtained differ from the behavior of the unlabeled conjugate that would be used as the macromolecular therapeutics?

\section{EXPERIMENTAL SECTION}

\subsection{Abbreviations}

\begin{tabular}{|c|c|}
\hline APMA & $\mathrm{N}$-(3-Aminopropyl)methacrylamide hydrochloride \\
\hline Boc-GFLG-OMe & $\begin{array}{l}\text { Methyl9-benzyl-2,2-dimethyl-4,7,10,13-tetraoxo-12-propyl-3-oxa- } \\
5,8,11,14 \text {-tetraazahexadecan-16-oate }\end{array}$ \\
\hline Boc-GFLG-NH 2 & $\begin{array}{l}\text { Tert-Butyl(14-amino-4-benzyl-7-isobutyl-2,5,8,11-tetraoxo-3,6,9,12- } \\
\text { tetraazatetradecyl) } \\
\text { Carbamate }\end{array}$ \\
\hline CTA & Chain transfer agent (4-cyanopentanoic acid dithiobenzoate) \\
\hline CTA-GFLG-CTA & $\begin{array}{l}\text { 10-Benzyl-2,25-dicyano-13-isobutyl-5,8,11,14,17,22-hexaoxo- } \\
6,9,12,15,18,21 \text {-hexaazahexacosane-2,25-diyl dibenzodithioate }\end{array}$ \\
\hline DCC & $N, N^{\prime}$-Dicyclohexylcarbodiimide \\
\hline DMAP & 4-(Dimethylamino) pyridine \\
\hline EPI & Epirubicin \\
\hline Fmoc-Abu $\left(\mathrm{N}_{3}\right)-\mathrm{OH}$ & (S)-2-(Fmoc-amino)-4-azidobutanoic acid \\
\hline HPMA & $N$-(2-Hydroxypropyl)methacrylamide \\
\hline HATU & $\begin{array}{l}\text { 1-[Bis(dimethylamino)methylene]-1H-1,2,3-triazolo[4,5-b]pyridinium 3- } \\
\text { oxid } \\
\text { hexafluorophosphate }\end{array}$ \\
\hline HOBt & 1-Hydroxybenzotriazole \\
\hline${ }^{111}$ In -P-EPI- ${ }^{125}$ I & $\begin{array}{l}\text { Frist generation HPMA copolymer-EPI conjugate with }{ }^{111} \text { In-DTPA } \\
\text { labeled polymer back bone and }{ }^{125} \text { I-Tyr labeled EPI }\end{array}$ \\
\hline
\end{tabular}




\author{
${ }^{111}$ In-2P-EPI- ${ }^{125}$ | \\ ${ }^{125}$ I-2P-EPI- ${ }^{111}$ In \\ MA-Tyr- $\mathrm{NH}_{2}$ \\ MA-GFLG-OH \\ MA-GLFG-Abu $\left(\mathrm{N}_{3}\right)$ - \\ $\mathrm{OH}$
}

MA-GFLG-Abu(N $\left.\mathrm{N}_{3}\right)$ EPI

MA-GFLG-Abu(Tyr)EPI

MA-GFLG-NHBoc

MA-GG-EPI

$\mathrm{NH}_{2}$-GFLG-NH

p-SCN-Bn-DTPA

P-EPI

P-EPI-Tyr

P-EPI-N 3

P-DTPA-EPI(Tyr)

2P-EPI- $\mathrm{N}_{3}$

2P-DTPA-EPI(Tyr)

2P-Tyr-EPI-N 3

2P-Tyr-EPI(DTPA)

RAFT
Second generation HPMA copolymer-EPI conjugate with ${ }^{111}$ In-DTPA labeled polymer back bone and ${ }^{125} \mathrm{I}-\mathrm{Tyr}$ labeled EPI

Second generation HPMA copolymer-EPI conjugate with ${ }^{125} \mathrm{I}-\mathrm{Tyr}$ labeled polymer back bone and ${ }^{11}$ In-DTPA labeled EPI

$N$-Methacryloyltyrosinamide

$\mathrm{N}$-Methacryloylglycylphenylalanylleucylglycine

$\mathrm{N}$-(2-((4-Azido-1-(((2S,3R,4S,6R)-3-hydroxy-2-methyl-6-((3,5,12-

trihydroxy-3-(2-hydroxyacetyl)-10-methoxy-6,11-dioxo-1,2,3,4,6,11-

hexahydrotetracen-1-yl)oxy)tetrahydro-2H-pyran-4-yl)amino)-1-

oxobutan-2-yl)amino)-2-oxoethyl)-2-(2-(2-methacrylamidoacetamido)-

3-phenylpropanamido)-4-methylpentanamide

$\mathrm{N}$-(2-((4-Azido-1-(((2S,3R,4S,6R)-3-hydroxy-2-methyl-6-((3,5,12-

trihydroxy-3-(2-hydroxyacetyl)-10-methoxy-6,11-dioxo-1,2,3,4,6,11-

hexahydrotetracen-1-yl)oxy)tetrahydro-2H-pyran-4-yl)amino)-1-

oxobutan-2-yl)amino)-2-oxoethyl)-2-(2-(2-methacrylamidoacetamido)-

3-phenylpropanamido)-4-methylpentanamide

2-(4-(1-(12-Benzyl-3-(((2S,3R,4S,6R)-3-hydroxy-2-methyl-6-((3,5,12-

trihydroxy-3-(2-hydroxyacetyl)-10-methoxy-6,11-dioxo-1,2,3,4,6,11-

hexahydrotetracen-1-yl)oxy)tetrahydro-2H-pyran-4-yl)carbamoyl)-9-

isobutyl-18-methyl-5,8,11,14,17-pentaoxo-4,7,10,13,16-

pentaazanonadec-18-en-1-yl)-1H-1,2,3-triazol-5-yl)butanamido)-3-(4-

hydroxyphenyl)propanoic acid

Tert-Butyl(11-benzyl-8-isobutyl-17-methyl-4,7,10,13,16-pentaoxo-

3,6,9,12,15-pentaazaoctadec-17-en-1-yl)carbamate

$\mathrm{N}$-(2-((2-)((2S,3R,4S,6R)-3-Hydroxy-2-methyl-6-((3,5,12-trihydroxy-3-

(2-hydroxyacetyl)-10-methoxy-6,11-dioxo-1,2,3,4,6,11-

hexahydrotetracen-1-yl)oxy)tetrahydro-2H-pyran-4-yl)amino)-2-

oxoethyl)amino)-2-oxoethyl)methacrylamide

2-(2-(2-Aminoacetamido)-3-phenylpropanamido)-N-(2-((2-

aminoethyl)amino)-2-oxoethyl)-4-methylpentanamide

$2,2 '-((1-((2-)-(2-$

carboxyethyl)(carboxymethyl)amino)ethyl)(carboxymethyl)amino)-3-(4-

thiocyanatophenyl)propan-2-yl)azanediyl)diacetic acid

First generation HPMA and MA-GLFG-EPI copolymer conjugate

First generation HPMA and MA-GLFG-Abu(Tyr)-EPI copolymer conjugate

First generation HPMA, APMA and MA-GLFG-Abu $\left(\mathrm{N}_{3}\right)$-EPI copolymer conjugate

First generation HPMA copolymer-EPI conjugate with DTPA pendent on polymer back bone and tyrosine moiety attachment with EPI

Second generation HPMA, APMA and MA-GLFG-Abu( $\left.\mathrm{N}_{3}\right)$-EPI copolymer conjugate

Second generation HPMA copolymer-EPI conjugate with DTPA pendent on polymer back bone and tyrosine moiety attachment with EPI

Second generation HPMA, MA-Tyr- $\mathrm{NH}_{2}$ and MA-GLFG-Abu $\left(\mathrm{N}_{3}\right)$-EPI copolymer conjugate

Second generation HPMA copolymer-EPI conjugate with tyrosine moiety pendent on polymer back bone and DTPA attachment with EPI Reversible addition-fragmentation chain transfer 
TBTA

TFA

Tyr- $\mathrm{C} \equiv \mathrm{CH}$

$\mathrm{V}-65$

$\mathrm{V}-501$

VA-044
Tris(benzyltriazolylmethyl)amine

Trifluoroacetic acid

2-(Hex-5-ynamido)-3-(4-hydroxyphenyl)propanoic acid

2,2'-Azobis(2,4-dimethylvaleronitrile)

4,4-Azobis (4-cyanopentanoic acid)

2,2'-Azobis[2-(2-imidazolin-2-yl) propane]dihydrochloride

\subsection{Materials}

Common reagents were purchased from Sigma-Aldrich and used as received unless otherwise specified. 2,2'-Azobis(2,4-dimethylvaleronitrile) (V-65), 2,2'-azobis[2-(2-imidazolin-2-yl) propane]dihydrochloride (VA-044) were from Wako; 4,4-azobis (4-cyanopentanoic acid) (V-501) was from Fisher Scientific. N,N'-Dicyclohexylcarbodiimide (DCC), Fmoc-Abu( $\left.\mathrm{N}_{3}\right)-\mathrm{OH}(\mathrm{S})$-2-(Fmoc-amino)-4azidobutanoic acid and 4-(dimethylamino) pyridine (DMAP) were obtained from AAPPTEC. lodine-125 $\left[{ }^{125} \mathrm{I}\right]$ was obtained from Perkin-Elmer. ${ }^{111} \mathrm{InCl}_{3}$ was from Intermountain Radiopharmacy. 1Hydroxybenzotriazole (HOBt) and $N$-Boc-ethylenediamine were purchased from AnaSpec. 2,2'-((1-)(2((2-Carboxyethyl)(carboxymethyl)amino)ethyl)(carboxymethyl)amino)-3-(4-thiocyanatophenyl)propan-2yl)azanediyl)diacetic acid ( $p$-SCN-Bn-DTPA) was purchased from Macrocyclics. Reversible additionfragmentation chain transfer (RAFT) agent, 4-cyanopentanoic acid dithiobenzoate (chain transfer agent, CTA), was synthesized according to the literature [45].

\subsection{Methods}

\subsubsection{Synthesis of monomers}

$\mathrm{N}$-(2-Hydroxypropyl)methacrylamide (HPMA) was synthesized by acylating 1-aminopropan-2-ol with methacryloyl chloride in acetonitrile, as previously described [46]. Melting point: $69-71{ }^{\circ} \mathrm{C} ; \mathrm{N}$ methacryloyltyrosinamide (MA-Tyr- $\left.\mathrm{NH}_{2}\right)$ [47], N-methacryloylglycylphenylalanylleucylglycine (MAGFLG-OH), methyl 9-benzyl-2,2-dimethyl-4,7,10,13-tetraoxo-12-propyl-3-oxa-5,8,11,14tetraazahexadecan-16-oate (Boc-GFLG-OMe) [48] and N-(2-((2-((2S,3R,4S,6R)-3-hydroxy-2-methyl-6((3,5,12-trihydroxy-3-(2-hydroxyacetyl)-10-methoxy-6,11-dioxo-1,2,3,4,6,11-hexahydrotetracen-1yl)oxy)tetrahydro-2H-pyran-4-yl)amino)-2-oxoethyl)amino)-2-oxoethyl)methacrylamide (MA-GG-EPI) [49] were synthesized as previously described.

Synthesis of Tyr-CECH. Fmoc- $\mathrm{Tyr}(\mathrm{Bu})-\mathrm{OH}$ (230 mg, 0.5 eq.) and DIPEA (313 $\mu \mathrm{L}, 4$ eq.) were dissolved in $9 \mathrm{~mL}$ dry dichloromethane (DCM). The solution was added to the resin and shook for $2 \mathrm{~h}$ at room temperature (r.t.). The solution was drained and washed with $5 \times \mathrm{DCM} / \mathrm{MeOH} / \mathrm{DIPEA}(17 / 2 / 1,9$ $\mathrm{mL}), 3 \times$ DCM and $3 \times$ DMF. Kaiser Test showed a negative result. Piperidine/DMF (1/4, $9 \mathrm{~mL}$ ) was added and shook for $5 \mathrm{~min}$, a positive Kaiser Test result was showed by dark blue solution and beads. Hex-5-ynoic acid ( $140 \mathrm{mg}, 132 \mu \mathrm{L}, 2.5$ eq.), DIPEA (391 $\mu$ L, 5 eq.) and HATU ( $456 \mathrm{mg}, 2.4$ eq.) in $5 \mathrm{~mL}$ DMF were added and shook for about $2 \mathrm{~h}$. The solution was drained and washed with $3 \times$ DMF, $3 \times$ $\mathrm{DCM}$ and $3 \times \mathrm{MeOH}$. TFA/DCM (3/7, $9 \mathrm{~mL})$ was added and shook for $2 \mathrm{~h}$. After filtration and removing the solvent, $97 \mathrm{mg}$ of product was yield $(35 \%)$ as yellow oil. ${ }^{1} \mathrm{H} \mathrm{NMR}\left(300 \mathrm{MHz}, \mathrm{CD}_{3} \mathrm{OD}\right) \delta 1.67-1.74(\mathrm{~m}$, 
2H), 2.09-2.11 (m, 2H), $2.2(\mathrm{t}, 1 \mathrm{H}, \mathrm{J}=2.1), 2.26-2.29(\mathrm{~m}, 2 \mathrm{H}), 2.83(\mathrm{dd}, 1 \mathrm{H}, \mathrm{J}=10.5,6.9), 3.11(\mathrm{dd}, 1 \mathrm{H}$, $\mathrm{J}=10.5,6.9), 4.59(\mathrm{dd}, 1 \mathrm{H}, \mathrm{J}=6.9,3.6), 6.68-6.70(\mathrm{~m}, 2 \mathrm{H}), 7.03(\mathrm{dd}, 2 \mathrm{H}, \mathrm{J}=4.3,1.5)$.

Synthesis of MA-GLFG-Abu( $\left.\mathbf{N}_{3}\right)-\mathrm{OH}$. Fmoc-Abu( $\left.\mathrm{N}_{3}\right)-\mathrm{OH}(73 \mathrm{mg}, 0.5$ eq.) and DIPEA (139 $\mu \mathrm{L}, 4$ eq.) were dissolved in $4 \mathrm{~mL}$ dry DCM. The solution was added to the resin and shook for $2 \mathrm{~h}$ at r.t.. The solution was drained and the resin was washed with $5 \times \mathrm{DCM} / \mathrm{MeOH} / \mathrm{DIPEA}(17 / 2 / 1,6 \mathrm{~mL}), 3 \times \mathrm{DCM}$ and $3 \times$ DMF. Kaiser Test was negative. The solvent was drained and piperidine/DMF (1/4, $2.5 \mathrm{~mL})$ was added. After shaking for $5 \mathrm{~min}$, a positive Kaiser Test was obtained. MA-GFLG-OH (230 mg, 2.5 eq.), DIPEA (208 $\mu \mathrm{L}, 5$ eq.) and HBTU (182 mg, 2.4 eq.) in $2 \mathrm{~mL}$ DMF were added and shook for $2 \mathrm{~h}$. The solution was drained and washed with $3 \times$ DMF, $3 \times$ DCM, $3 \times \mathrm{MeOH}$. TFE/DCM (3/7, $4 \mathrm{~mL})$ was added and shook for $2 \mathrm{~h}$. After filtration and removing the solvent, $95 \mathrm{mg}$ of product was yield by precipitation in ethyl ether (81\%) as white powder.

Synthesis of MA-GLFG-Abu( $\left.\mathbf{N}_{3}\right)$-EPI. Under $\mathrm{N}_{2}$ atmosphere, MA-GLFG-Abu( $\left.\mathrm{N}_{3}\right)-\mathrm{OH}(30 \mathrm{mg}, 0.05$ mmol), DIPEA (23 $\mu \mathrm{L}, 0.13 \mathrm{mmol})$ and HATU (19 mg, $0.05 \mathrm{mmol})$ were dissolved in $400 \mu \mathrm{L}$ DMF. 2 min later, EPI (27 mg, $0.05 \mathrm{mmol}$ ) was added and the solution was stirred at r.t. for $1 \mathrm{~h}$. Ethyl acetate (100 $\mathrm{mL})$ was added and the solution was washed with $\mathrm{NaHCO}_{3}(0.1 \mathrm{M}, 50 \mathrm{~mL}), \mathrm{HCl}(0.1 \mathrm{M}, 50 \mathrm{~mL})$ and $\mathrm{NaCl}$ (sat., $50 \mathrm{~mL}$ ) three times, respectively. The organic layer was dried with anhydrous $\mathrm{MgSO}_{4}$ and the solvent was removed under vacuum. The residue was precipitated into ethyl ether to yield $30 \mathrm{mg}$ of product as red powder (yield 54\%). The structure and purity of the product were confirmed by MALDITOF-MS and HPLC (Agilent ZORBAX, $5 \mu \mathrm{m}$, 300SB-C18 column $4.6 \times 250 \mathrm{~mm}$, using flow rate 1.0 $\mathrm{mL} / \mathrm{min}$ and gradient elution from $2 \%$ to $90 \%$ of buffer $\mathrm{B}$ within 30 min. Buffer $\mathrm{A}$ : DI $\mathrm{H}_{2} \mathrm{O}$ with $0.1 \%$ TFA, Buffer B: acetonitrile with 0.1\% TFA) analysis. MS (MALDI-TOF) m/z: $1134.46[\mathrm{M}+\mathrm{Na}]^{+}, 1150.43[\mathrm{M}+\mathrm{K}]^{+}$.

Synthesis of MA-GFLG-Abu(Tyr)-EPI. MA-GFLG-Abu( $\left.\mathrm{N}_{3}\right)$-EPI (36 mg, $32 \mu \mathrm{mol}$ ) was dissolved in $600 \mu \mathrm{L}$ DMF and purged with $\mathrm{N}_{2}$ for $20 \mathrm{~min}$. TyrC $\mathrm{CH}$ (40 mg, $\left.145 \mu \mathrm{mol}\right), \mathrm{CuBr}(4.5 \mathrm{mg}, 32 \mu \mathrm{mol})$ and tris(benzyltriazolylmethyl)amine (TBTA) $(15 \mathrm{mg}, 32 \mu \mathrm{mol})$ were dissolved in $400 \mu \mathrm{L}$ DMF (purged with $\mathrm{N}_{2}$ for $20 \mathrm{~min}$ ) and added into the MA-GFLG-Abu(N)-EPI solution. The mixture was stirred at r.t. and purged with $\mathrm{N}_{2}$ for 20 min. Ascorbic acid (100 mg/mL $\times 54 \mu \mathrm{L}$, in $\mathrm{H}_{2} \mathrm{O}$ purged with $\mathrm{N}_{2}$ for 20 min) was added and stirred at room temperature overnight. After working up, added $150 \mathrm{~mL}$ of ethyl acetate and washed with $\mathrm{HCl}(2 \times 50 \mathrm{~mL}, 0.5 \mathrm{M})$. The aqueous phase turned red after washing with $\mathrm{NaHCO}_{3}$ (sat., $50 \mathrm{~mL}$ ). The $\mathrm{pH}$ value was adjusted to about 1 with $\mathrm{HCl}(1 \mathrm{M})$ and the aqueous layer was extracted with ethyl acetate $(3 \times 50 \mathrm{~mL})$. The organic phase was combined and dried with anhydrous $\mathrm{MgSO}_{4}$. The solvent was removed by rotary evaporation below $35^{\circ} \mathrm{C}$, the residue was precipitated into ethyl ether to yield $19 \mathrm{mg}$ of product as red powder (yield 42\%). The structure and purity of the product were confirmed by MALDI-TOF-MS and HPLC analysis. MS (MALDI-TOF) m/z: 1409.60 [M+Na] ${ }^{+}, 1425.59$ $[\mathrm{M}+\mathrm{K}]^{+}$.

\subsubsection{Synthesis of diarm chain transfer agent CTA-GFLG-CTA (Fig. S5)}

Boc-GFLG-OMe (505 mg, $1 \mathrm{mmol}$ ) was dissolved in $\mathrm{CH}_{3} \mathrm{OH}(5 \mathrm{~mL}), \mathrm{NH}_{2}\left(\mathrm{CH}_{2}\right)_{2} \mathrm{NH}_{2}(647 \mu \mathrm{L}, 10$ mmol) was added and stirred at r.t. for $3 \mathrm{~h}$. After working up, the solvent and part of $\mathrm{NH}_{2}\left(\mathrm{CH}_{2}\right)_{2} \mathrm{NH}_{2}$ were removed by rotary evaporation below $35{ }^{\circ} \mathrm{C}$; then $150 \mathrm{~mL}$ ethyl acetate were added. After washing with $\mathrm{H}_{2} \mathrm{O}(3 \times 50 \mathrm{~mL})$ and $\mathrm{NaCl}$ (sat. $3 \times 50 \mathrm{~mL}$ ), the organic phase was dried with $\mathrm{MgSO}_{4}$, the 
solvent was removed by rotary evaporation to yield $361 \mathrm{mg}$ of product as white solid (Boc-GFLG-NH${ }_{2}$, $68 \%)$.

Boc-GFLG-NH $\mathrm{N}_{2}(390 \mathrm{mg}, 0.73 \mathrm{mmol})$ was dissolved in DCM $(10 \mathrm{~mL}), 4 \mathrm{~mL}$ TFA was added and stirred at r.t. for $4 \mathrm{~h}$ and at $4{ }^{\circ} \mathrm{C}$ overnight. After removing the solvent, the product was dried under reduced pressure to yield $\mathrm{NH}_{2}$-GFLG-NH $\mathrm{N}_{2}$-2TFA as white solid (315 mg, 98\%). CTA (217 mg, 0.78 $\mathrm{mmol})$, DCC (167 mg, $0.8 \mathrm{mmol}$ ) and HOBt (105 mg, $0.78 \mathrm{mmol})$ were dissolved in DMF/acetonitrile (2 $\mathrm{mL} / 10 \mathrm{~mL}$ ). The solution was stirred for $30 \mathrm{~min}$ at r.t. $\mathrm{NH}_{2}-\mathrm{GFLG}-\mathrm{NH}_{2} \cdot 2 \mathrm{TFA}$ (173 $\mathrm{mg}, 0.26 \mathrm{mmol}$ ) was dissolved in $5 \mathrm{~mL}$ acetonitrile with $104 \mu \mathrm{L}$ DIPEA (0.6 mmol). After $30 \mathrm{~min}$, the solution (containing $\mathrm{NH}_{2^{-}}$ GFLG-NH $\mathrm{N}_{2}$ ) was added to the CTA solution and stirred at room temperature overnight. After working up, filtered and removed solvent, $600 \mathrm{~mL}$ ethyl acetate was added and washed with $\mathrm{HCl}(0.5 \mathrm{M}, 3 \times 100$ $\mathrm{mL}$ ), $\mathrm{NaHCO}_{3}$ (sat., $3 \times 100 \mathrm{~mL}$ ) and $\mathrm{NaCl}$ (sat. $1 \times 100 \mathrm{~mL}$ ). The organic phase was combined and dried by $\mathrm{MgSO}_{4}$, the solvent was removed by rotary evaporation below $35^{\circ} \mathrm{C}$. The residue was purified by silica gel column chromatography (acetone : petroleum ether $=1: 5 \sim 5: 1$ ) to yield CTA-GFLG-CTA as pink solid (260 mg, 50\%). The purity and structure of CTA-GFLG-CTA were confirmed by HPLC, NMR and MALDI-TOF-MS analysis (Fig. S6). ${ }^{1} \mathrm{H}$ NMR (400 MHz, $\left.\mathrm{CD}_{3} \mathrm{OD}\right) \delta$ 0.71-0.79 (m, 3H), 0.88$0.92(\mathrm{~m}, 3 \mathrm{H}), 1.43-1.48(\mathrm{~m}, 1 \mathrm{H}), 1.50-1.68(\mathrm{~m}, 1 \mathrm{H}), 1.93(\mathrm{~s}, 6 \mathrm{H}), 2.36-2.43(\mathrm{~m}, 2 \mathrm{H}), 2.51-2.59(\mathrm{~m}, 6 \mathrm{H})$, 2.93-3.03 (m, 2H), 3.16-3.23 (m, 1H), 3.70-3.91 (m, 4H), 4.07-4.20 (m, 1H), 4.45-4.86 (m, 1H), 7.22$7.26(\mathrm{~m}, 5 \mathrm{H}), 7.44-7.44(\mathrm{~m}, 4 \mathrm{H}), 7.59(\mathrm{~s}, 2 \mathrm{H}), 7.91-7,92(\mathrm{~m}, 4 \mathrm{H}) . \mathrm{MS}$ (MALDI-TOF) m/z: 957.35 [M+H] ${ }^{+}$, $979.33[\mathrm{M}+\mathrm{Na}]^{+}$.

\subsubsection{Synthesis of HPMA copolymer-EPI conjugates}

\subsubsection{Synthesis of first generation HPMA copolymer-EPI conjugate P-DTPA-EPI(Tyr)}

Synthesis of P-EPI-N $\mathbf{N}_{3}$. An ampoule containing HPMA (92 mg, $\left.0.69 \mathrm{mmol}, 92 \%\right)$, APMA (5.1 mg, $0.027 \mathrm{mmol}, 4 \%$ ) and MA-GFLG-Abu( $\left.\mathrm{N}_{3}\right)$-EPI (30 mg, $0.027 \mathrm{mmol}, 4 \%$ ) were attached to the Schlenkline. After three vacuum-nitrogen cycles to remove oxygen, $150 \mu \mathrm{L}$ degassed $\mathrm{MeOH}$ was added and stirred at r.t.. CTA $(2.3 \mathrm{mg} / \mathrm{mL} \times 150 \mu \mathrm{L}, 0.000622 \mathrm{mmol}$, in degassed $\mathrm{MeOH})$ and VA-044 $(1 \mathrm{mg} / \mathrm{mL} \times$ $145 \mu \mathrm{L}, 0.000201 \mathrm{mmol}$, in degassed $\mathrm{H}_{2} \mathrm{O}$ ) were added via syringe under magnetic stirring and bubbled

with $\mathrm{N}_{2}$ for $10 \mathrm{~min}$ in ice bath. The ampoule was sealed, and polymerization was performed at $40{ }^{\circ} \mathrm{C}$ for

$22 \mathrm{~h}$. The copolymer was obtained by precipitation into acetone/ethyl ether (3:1) and purified by redissolving in methanol and precipitation in acetone/ethyl ether (3:1) two more times. The copolymer was isolated as red powder and dried under vacuum. Yield: $24 \mathrm{mg}(19 \%)$.

The average molecular weight $(M w)$ and the polydispersity $(P D I)$ of the conjugates were determined by size-exclusion chromatography (SEC) on an AKTA FPLC system equipped with a UV detector (GE Healthcare), mini DAWN TREOS, and OptilabrEX (refractive index) detector (Wyatt Technology) using a Superose 6 HR10/30 column with sodium acetate buffer containing 30\% (vol/vol) acetonitrile (pH 6.5) as mobile phase. HPMA homopolymer fractions were used as molecular weight standards.

The red powder $(24 \mathrm{mg})$ was further reacted with V-65 $(8.4 \mathrm{mg}, 0.034 \mathrm{mmol}$, over 40-times excess with respect to the polymer end groups) in $0.3 \mathrm{~mL} \mathrm{MeOH}$ at $55^{\circ} \mathrm{C}$ for $2 \mathrm{~h}$, purified by precipitation into acetone/ethyl ether (3:1) twice, resulting in intermediate P-EPI- $\mathrm{N}_{3}$. The polymer was analyzed by 
ninhydrin assay [50] to determine amino content. The EPI content of copolymers was determined spectrophotometrically with free EPI standard working curve. ([NH 2$]: 216 \mathrm{nmol} / \mathrm{mg}$ polymer; [EPI]: 10.5 wt\%)

Attachment of Tyrosine moiety and DTPA chelator. The polymer precursor (P-EPI- $\mathrm{N}_{3}, 23 \mathrm{mg}$ ) was dissolved in $200 \mu \mathrm{L}$ DMF and purged with $\mathrm{N}_{2}$ for 20 min. $\mathrm{TyrC} \equiv \mathrm{CH}$ (3 eq.), $\mathrm{CuBr}$ (1 eq.) and TBTA (1 eq.) were dissolved in $200 \mu \mathrm{L}$ DMF (purged with $\mathrm{N}_{2}$ for $20 \mathrm{~min}$ ) and added into the polymer precursor solution. The mixture was stirred at room temperature and purged with $\mathrm{N}_{2}$ for $20 \mathrm{~min}$. Ascorbic acid (10 eq, in $\mathrm{H}_{2} \mathrm{O}$ purged with $\mathrm{N}_{2}$ for $20 \mathrm{~min}$ ) was added and the mixture was stirred at room temperature overnight. After purification by ultrafiltration (10,000 Da cut-off, Millipore) with $\mathrm{DI} \mathrm{H}_{2} \mathrm{O}$ three times and freeze drying, the product was obtained as red powder (16 mg, 71\%). The red powder (15 mg) was dissolved in $400 \mu \mathrm{L} \mathrm{NaHCO}_{3}$ buffer $(0.2 \mathrm{M}$, containing $10 \mathrm{mM}$ EDTA, pH 8.5) and mixed with $p$-SCN-BnDTPA (10 mg) in $200 \mu \mathrm{L}$ DMSO. After stirring at room temperature overnight, the sample was applied to a pre-equilibrated PD-10 Sephadex G25 column (GE Healthcare) with DI $\mathrm{H}_{2} \mathrm{O}$ for primary purification. The fraction of $2.5-4.5 \mathrm{~mL}$ was collected and further purified by ultrafiltration $(10,000 \mathrm{Da}$ cut-off) with $\mathrm{NaHCO}_{3}$ buffer three times and $\mathrm{DI} \mathrm{H}_{2} \mathrm{O}$ three times. The final product in $\mathrm{DI}_{2} \mathrm{O}$ was freeze dried to remove solvent (13 mg, P-DTPA-EPI(Tyr), 87\%). The DTPA content was determined using spectrophotometric method [51]. The content of DTPA in P-DTPA-EPI(Tyr) was calculated as 140 $\mathrm{nmol} / \mathrm{mg}$ polymer. The conversion was $64 \%$.

\subsubsection{Synthesis of second generation HPMA copolymer-EPI conjugate 2P-DTPA-EPI(Tyr)}

Synthesis of 2 P-EPI- $\mathbf{N}_{3}$. An ampoule containing HPMA (80 mg, $0.56 \mathrm{mmol}, 93 \%$ ), APMA (3.4 mg, $0.02 \mathrm{mmol}, 4 \%$ ) and MA-GFLG-Abu( $\left.\mathrm{N}_{3}\right)$-EPI (20 mg, $0.018 \mathrm{mmol}, 3 \%$ ) was attached to the Schlenk-line. After three vacuum-nitrogen cycles to remove oxygen, $136 \mu \mathrm{L}$ degassed $\mathrm{MeOH}$ was added and the reaction mixture stirred at r.t.. CTA-GFLG-CTA $(10 \mathrm{mg} / \mathrm{mL} \times 38 \mu \mathrm{L}, 0.0004 \mathrm{mmol}$, in degassed $\mathrm{MeOH})$ and VA-044 (2 mg/mL $\times 36 \mu \mathrm{L}, 0.000223 \mathrm{mmol}$, in degassed $\mathrm{H}_{2} \mathrm{O}$ ) were added via syringe under magnetic stirring and bubbled with $\mathrm{N}_{2}$ for $10 \mathrm{~min}$ in ice bath. The ampoule was sealed, and polymerization was performed at $40{ }^{\circ} \mathrm{C}$ for $44 \mathrm{~h}$. The copolymer was obtained by precipitation into acetone/ethyl ether (3:1) and purified by redissolving in methanol and precipitation in acetone/ethyl ether (3:1) two more times. The copolymer was isolated as red powder and dried under vacuum. Yield: $35 \mathrm{mg}$ (34\%). The red powder (35 mg) was further reacted with V-65 (5.3 mg, $0.034 \mathrm{mmol}$, over 40times excess with respect to the polymer end groups) in $0.4 \mathrm{~mL} \mathrm{MeOH}$ at $55^{\circ} \mathrm{C}$ for $2 \mathrm{~h}$, purified by precipitation into acetone/ether (3:1) twice, resulting in intermediate $2 \mathrm{P}-\mathrm{EPI}-\mathrm{N}_{3}$. EPI and amino group content were determined by the same methods as P-EPI- $\mathrm{N}_{3}$ (see 2.3.3.1). ([EPI]: $9.7 \mathrm{wt} \%$; [ $\left.\mathrm{NH}_{2}\right]: 320$ $\mathrm{nmol} / \mathrm{mg}$ polymer).

Attachment of Tyrosine moiety and DTPA chelator The synthetic method was the same as 2.3.3.1. Obtained $15 \mathrm{mg}$ of final product (yield 87\%). The content of DTPA in 2P-DTPA-EPI(Tyr) was determined as $83 \mathrm{nmol} / \mathrm{mg}$ polymer.

\subsubsection{Synthesis of second generation conjugate 2P-Tyr-EPI-DTPA}

Synthesis of 2P-Tyr-EPI-N $\mathbf{3}_{3}$. An ampoule containing HPMA (80 mg, $0.56 \mathrm{mmol}, 93 \%$ ), MA-Tyr-NH (3 mg, $0.013 \mathrm{mmol}, 2.2 \%$ ) and MA-GFLG-Abu( $\left.\mathrm{N}_{3}\right)$-EPI (20 mg, $0.018 \mathrm{mmol}, 3 \%$ ) was attached to the Schlenk-line. After three vacuum-nitrogen cycles to remove oxygen, $46 \mu \mathrm{L}$ degassed $\mathrm{MeOH}$ was added 
and the mixture was stirred at r.t. CTA-GFLG-CTA ( $3 \mathrm{mg} / \mathrm{mL} \times 128 \mu \mathrm{L}, 0.4 \square \mathrm{mol}$, in degassed $\mathrm{MeOH}$ ) and VA-044 ( $2 \mathrm{mg} / \mathrm{mL} \times 36 \mu \mathrm{L}, 0.223 \square \mathrm{mol}$, in de-gassed $\left.\mathrm{H}_{2} \mathrm{O}\right)$ were added via syringe under magnetic stirring and bubbled with $\mathrm{N}_{2}$ for 10 min in ice bath. The ampoule was sealed, and polymerization was performed at $40^{\circ} \mathrm{C}$ for $44 \mathrm{~h}$. The copolymer was obtained by precipitation into acetone/ethyl ether (3:1) and purified by redissolving in methanol and precipitation in acetone/ethyl ether (3:1) two more times. The copolymer was isolated as red powder and dried under vacuum. Yield: $40 \mathrm{mg}(39 \%)$. The red powder $(40 \mathrm{mg})$ was further reacted with V-65 $(5.3 \mathrm{mg}, 0.034 \mathrm{mmol}$, over 40-times excess with respect

to the polymer end groups) in $0.4 \mathrm{~mL} \mathrm{MeOH}$ at $55{ }^{\circ} \mathrm{C}$ for $2 \mathrm{~h}$, purified by precipitation into acetone/ethyl ether (3:1) twice, resulting in 2P-Tyr-EPI- $\mathrm{N}_{3}$. The EPI content was 5.5 wt\%.

Attachment of DTPA chelator. 2P-Tyr-EPI- $\mathrm{N}_{3}$ (30 mg, 1 eq.), propargylamine (1.2 mg, 3 eq.), $\mathrm{CuBr}\left(1.0 \mathrm{mg}, 1\right.$ eq.) and TBTA (3.0 mg, 1 eq.) were dissolved in $400 \mu \mathrm{L}$ DMF and purged with $\mathrm{N}_{2}$ for $20 \mathrm{~min}$. The mixture was stirred at room temperature and purged with $\mathrm{N}_{2}$ for $20 \mathrm{~min}$. Ascorbic acid (100 $\mathrm{mg} / \mathrm{mL} \times 12 \mu \mathrm{L}$, in $\mathrm{H}_{2} \mathrm{O}$ which was purged with $\mathrm{N}_{2}$ for $20 \mathrm{~min}$ ) was added and stirred at room temperature overnight. After working up, the reaction mixture was purified by ultrafiltration (30,000 Da cut-off) with $\mathrm{DI} \mathrm{H}_{2} \mathrm{O}$ three times. The remnant was precipitated in $14 \mathrm{~mL}$ acetone/ethyl ether (4:1) twice. $24 \mathrm{mg}$ of red powder was obtained (73\%). Amino content was determined as $75 \mathrm{nmol} / \mathrm{mg}$ polymer. Red powder $\left(20 \mathrm{mg}\right.$ ) was dissolved in $0.8 \mathrm{~mL}$ of $\mathrm{NaHCO}_{3}(0.2 \mathrm{M})$ containing $10 \mathrm{mM}$ EDTA (pH 8.5), then mixed with $p$-SCN-Bn-DTPA $(10 \mathrm{mg})$ in $200 \mu \mathrm{L}$ of DMSO. After stirring at room temperature overnight, the sample was applied to a pre-equilibrated PD-10 Sephadex G25 column (GE Healthcare) with DI $\mathrm{H}_{2} \mathrm{O}$ for primary purification. The fraction of $2.5-4.5 \mathrm{~mL}$ was collected and further purified by ultrafiltration (30,000 Da cut-off) with $\mathrm{NaHCO}_{3}$ buffer three times and $\mathrm{DI}_{2} \mathrm{O}$ three times. The final sample in $\mathrm{DI} \mathrm{H}_{2} \mathrm{O}$ was freeze dried to remove solvent (16 mg, $80 \%$ ). The content of DTPA was determined spectrophotometrically (16 nmol/mg) [51]. The conversion was $22 \%$.

\subsubsection{Synthesis of conjugates P-EPI and P-EPI(Tyr) for Tritosomes cleavage kinetic study}

An ampoule containing $50 \mathrm{mg}$ (or $73 \mathrm{mg}$ ) of HPMA and $10 \mathrm{mg}$ of MA-GFLG-EPI (or $7 \mathrm{mg} \mathrm{MA-}$ GFLG-Abu(Tyr)-EPI) was attached to the Schlenk-line. After three vacuum-nitrogen cycles to remove oxygen, $100 \mu \mathrm{L}$ (or $120 \mu \mathrm{L}$ ) degassed $\mathrm{MeOH}$ was added and stirred at r.t.. CTA, $4 \mathrm{mg} / \mathrm{mL} \times 50 \mu \mathrm{L}$ (or 2 $\mathrm{mg} / \mathrm{mL} \times 70 \mu \mathrm{L}$ ) in degassed $\mathrm{MeOH}$ and $2 \mathrm{mg} / \mathrm{mL} \times 39 \mu \mathrm{L}$ (or $2 \mathrm{mg} / \mathrm{mL} \times 27 \mu \mathrm{L}$ ) of VA-044 in degassed $\mathrm{MeOH}$ were added via syringe under magnetic stirring and bubbled with $\mathrm{N}_{2}$ for $10 \mathrm{~min}$ in ice bath. The ampoule was sealed, and polymerization was performed at $44^{\circ} \mathrm{C}$ for $22 \mathrm{~h}$. The copolymer was obtained by precipitation into acetone/ethyl ether (3:1) and purified by redissolving in methanol and precipitation in acetone/ethyl ether (3:1) two more times. The copolymer was isolated as red powder and dried under vacuum. Yield: $47 \mathrm{mg}$ of P-EPI (57\%) and $26 \mathrm{mg}$ of P-EPI(Tyr) (46\%). After end-modification with 40times excess of $\mathrm{V}-65$, the EPI content of copolymers was determined spectrophotometrically as 86 $\mathrm{nmol} / \mathrm{mg}$ polymer for P-EPI and $120 \mathrm{nmol} / \mathrm{mg}$ polymer for P-EPI(Tyr).

\subsubsection{Radiolabeling}

${ }^{125}$ I labeling of tyrosine moiety and ${ }^{111}$ In labeling of DTPA were conducted immediately before use by the method as previously described [26]. For single labeling of ${ }^{125}$ I, HPMA copolymer-EPI conjugates, containing tyrosine amide in the side chains or pendant on the backbones, were reacted with $\mathrm{Na}^{125}$ I 
(Perkin-Elmer) at r.t. in $0.01 \mathrm{M}$ phosphate buffer containing chloramine-T for $30 \mathrm{~min}$. After purification with ultrafiltration (10,000 Da cut-off tube for first generation conjugate and 30,000 Da cut-off for second generation conjugates), the copolymer with ${ }^{125}$ l labeling in $0.1 \mathrm{M}$ sodium acetate solution ( $\mathrm{pH}$ 5.2) was mixed with an aqueous solution of ${ }^{111} \mathrm{InCl}_{3}$ at r.t. for $30 \mathrm{~min}$ and then purified by ultrafiltration $(10,000$ Da cut-off for first generation conjugate and 30,000 Da cut-off for second generation conjugates) to produce dual radiolabeled conjugates.

\subsubsection{Tritosomes cleavage of P-EPI, P-EPI(Tyr)}

\subsubsection{Tritosomes preparation and activity toward Bz-Phe-Val-Arg-NAp substrate}

Rat liver Tritosomes were prepared according to the method of Trouet [52]. Briefly, $20 \%$ Triton WR1339 in $\mathrm{NaCl}(0.15 \mathrm{M})$ solution was intraperitoneally injected into rats $(1 \mathrm{~mL}$ per $100 \mathrm{~g}$ of rat weight). After 4 days, the rats were sacrificed, liver isolated and placed into $0.25 \mathrm{M}$ sucrose solution at $4{ }^{\circ} \mathrm{C}$. The liver was diced into little pieces and pushed through a strainer. The mixture was homogenized gently and centrifuged at $2400 \mathrm{rpm}$ for $10 \mathrm{~min}$ at $4{ }^{\circ} \mathrm{C}$. The supernatants were collected and the pellet was washed with $0.25 \mathrm{M}$ sucrose solution and centrifuged at $2400 \mathrm{rpm}$ for $10 \mathrm{~min}$ at $4{ }^{\circ} \mathrm{C}$. The combined supernatants were centrifuged at $22700 \mathrm{rpm}$ for $10 \mathrm{~min}$ at $4{ }^{\circ} \mathrm{C}$. The supernatant and the pink fluffy layer were removed. The pellets were centrifuged at $22700 \mathrm{rpm}$ for $10 \mathrm{~min}$ at $4^{\circ} \mathrm{C}$ and the supernatant and pink fluffy layer were removed again. The pellets and $45 \%$ sucrose solution were thoroughly mixed gently. A $34.5 \% \mathrm{w} / \mathrm{w}$ sucrose solution was added on the top of the $45 \%$ sucrose/pellet mixture and $14.3 \% \mathrm{w} / \mathrm{w}$ sucrose solution was added on the top of $34.5 \%$ sucrose solution. The mixture was centrifuged at $24000 \mathrm{rpm}$ for $2 \mathrm{~h}$ at $4{ }^{\circ} \mathrm{C}$. The lysosomal fraction (Tritosomes) was the layer between the $34.5 \%$ and $14.3 \%$ sucrose solutions.

Tritosomes activity toward Bz-Phe-Val-Arg-NAp substrate: Tritosomes $(0.1 \mathrm{~mL})$ were mixed with $0.84 \mathrm{~mL}$ sodium phosphate buffer (213 mM sodium phosphate, $44 \mathrm{mM}$ citrate, $\mathrm{pH} 5.5$ ), $0.02 \mathrm{~mL}$ glutathione $(0.25 \mathrm{M})$ in sodium phosphate buffer and $0.02 \mathrm{~mL} 10 \%$ Triton-X-100 in sodium phosphate buffer. The mixture was incubated at $37^{\circ} \mathrm{C}$ for $5 \mathrm{~min}$. The substrate (Bz-Phe-Val-Arg-NAp) solution ( $0.00102 \mathrm{~g}$ in $0.138 \mathrm{ml} \mathrm{DMSO}$ ) was added and incubated at $37^{\circ} \mathrm{C}$ for $15 \mathrm{~min}$. The absorption of cleaved p-nitroaniline was measured at $410 \mathrm{~nm}$. Within $10 \mathrm{~min}, 4.7 \%$ of $p$-nitroaniline was released from Bz-Phe-Val-Arg-NAp.

\subsubsection{Tritosomes cleavage of P-EPI, P-EPI(Tyr)}

Tritosomes $(0.48 \mathrm{~mL})$ were mixed with $0.40 \mathrm{~mL}$ buffer B-GSH $(27 \mathrm{mM}$ citrate, $20 \mathrm{mM}$ sodium phosphate, $2 \mathrm{mM}$ EDTA, $5 \mathrm{mM}$ glutathione, pH 4.6) and $0.02 \mathrm{~mL} 10 \%$ Triton-X-100 $(0.1 \mathrm{~g} / \mathrm{mL}$ in B-GSH buffer). After incubation for $5 \mathrm{~min}$ at $37{ }^{\circ} \mathrm{C}$, conjugate $(35 \mathrm{mg} / \mathrm{mL} \times 0.1 \mathrm{~mL}$ of P-EPI or $25 \mathrm{mg} / \mathrm{mL} \times 0.1$ $\mathrm{mL}$ of $\mathrm{P}$ - $\mathrm{EPI}(\mathrm{Tyr})$ in $\mathrm{H}_{2} \mathrm{O}$ ) was added into the mixture and incubated at $37^{\circ} \mathrm{C}$. At predetermined time intervals samples $(0.1 \mathrm{~mL})$ were withdrawn, added $0.05 \mathrm{~mL}$ of iodoacetic acid sodium $\left(1 \mathrm{mg} / \mathrm{mL}\right.$ in $\mathrm{H}_{2} \mathrm{O}$, inhibitor) and $0.05 \mathrm{~mL}$ of daunomycin $\left(0.1 \mathrm{mg} / \mathrm{mL}\right.$ in $\mathrm{H}_{2} \mathrm{O}$, internal standard for P-EPI and P-EPI(Tyr)). After centrifugation for $5 \mathrm{~min}$ (13 $500 \mathrm{rpm}$ ), $80 \mu \mathrm{L}$ of supernatant was analyzed by HPLC. Gradient elution: $20 \%$ B to $35 \%$ B in $25 \mathrm{~min}, 35 \% \mathrm{~B}$ to $60 \% \mathrm{~B}$ in $15 \mathrm{~min}, 60 \% \mathrm{~B}$ to $90 \% \mathrm{~B}$ in $15 \mathrm{~min}$ for P-EPI and P-EPI(Tyr). Time intervals: $1 \mathrm{~min}, 1,2,4,6,8,23$, and $48 \mathrm{~h}$. 


\subsubsection{Cleavage of P-DTPA-EPI(Tyr), 2P-DTPA-EPI(Tyr) and 2P-Tyr-EPI(DTPA) by Tritosomes}

Tritosomes $(200 \mu \mathrm{L})$ were buffer changed with phosphate buffer-A $(200 \mathrm{mM}, 0.2 \%$ Triton- $X-100$, EDTA $2 \mathrm{mM}, \mathrm{pH}$ 5.5) and mixed with $5 \mu \mathrm{L}$ of glutathione (100 mM). After incubation at $37^{\circ} \mathrm{C}$ for $5 \mathrm{~min}$, P-DTPA-EPI(Tyr) (2P-DTPA-EPI(Tyr) or 2P-Tyr-EPI(DTPA), $50 \mathrm{mg} / \mathrm{mL} \times 10 \mu \mathrm{L}$ in $\mathrm{H}_{2} \mathrm{O}$ ) was added and incubated at $37^{\circ} \mathrm{C}$. After $45 \mathrm{~h}$, to $200 \mu \mathrm{L}$ of reaction mixture was added $20 \mu \mathrm{L}$ of iodoacetic acid sodium ( $2 \mathrm{mg} / \mathrm{mL}$ in $\mathrm{H}_{2} \mathrm{O}$, inhibitor) and daunomycin $(2 \mathrm{mg} / \mathrm{mL} \times 4 \mu \mathrm{L}$ in $\mathrm{MeOH}$; internal standard for 2P-DTPA$\mathrm{EPI}(\mathrm{Tyr})$ and 2P-Tyr-EPI(DTPA)). The mixture was centrifuged for $5 \mathrm{~min}(13500 \mathrm{rpm})$. The supernatant was analyzed by HPLC. Tritosomes cleavage products were collected and determined by MALDI-TOFMS. The Tritosomes cleavage products of 2P-DTPA-EPI(Tyr) include [G-EPI-Tyr+Na] ${ }^{+}, 1024.39$ and $[\mathrm{EPI}-\mathrm{Tyr}+\mathrm{Na}]^{+}$, 967.37. The Tritosomes cleavage products of 2P-Tyr-EPI(DTPA) include [LG-EPIDTPA+Ca+2K] ${ }^{+}, 1549.39$, [G-EPI-DTPA+Ca+3K] ${ }^{+}, 1492.28$ and [EPI-DTPA+Zn+2K+2Na] ${ }^{+}, 1447.22$.

\subsubsection{Cell culture}

A2780 human ovarian carcinoma cells (ATCC) were maintained at $37{ }^{\circ} \mathrm{C}$ in a humidified atmosphere containing $5 \% \mathrm{CO}_{2}$ in RPMI-1640 medium (Gibco) supplemented with $10 \%$ FBS and a mixture of antibiotics (100 units $/ \mathrm{mL}$ penicillin, $0.1 \mathrm{mg} / \mathrm{mL}$ streptomycin).

\subsubsection{Tumor model}

All animal studies were carried out in accordance with the University of Utah Institutional Animal Care and Use Committee guidelines under approved protocols. A2780 human ovarian cancer cells $(5 \times$ $10^{6}$ ) in $100 \mu \mathrm{L}$ of PBS were subcutaneously inoculated in the right flank of 6 - to 8-wk-old syngeneic female nude mice (22-25 g; Charles River Laboratories).

\subsubsection{Pharmacokinetics and biodistribution study}

For pharmacokinetic study, 6-8 week-old healthy female nude mice (22-25 g; Charles River Laboratories) $(n=5)$ were intravenously injected with dual-radiolabeled HPMA copolymer-EPI conjugates ( $1 \mathrm{mg}, 20 \mu \mathrm{Ci}$ per mouse), respectively. At predetermined intervals, blood samples (10 $\mu \mathrm{L})$ were taken from the tail vein, and the radioactivity of each sample was measured with Gamma Counter (Packard). The ${ }^{125}$ activity was counted in a channel with windows set for $15-85 \mathrm{keV}$ and ${ }^{111} \mathrm{In}$ activity was counted in a channel having windows set for 237-257 keV [26]. Cross-counts in the ${ }^{125}$ channel were $5 \%$ and in the ${ }^{111}$ In channel were $1.5 \%$. Gross cpm values were corrected to compensate for cross-counting. The blood pharmacokinetic parameters for the radiotracer were analyzed using a noncompartmental model with WinNonlin 5.0.1 software (Pharsight).

For biodistribution study, 6-8 week-old female nude mice bearing s.c. A2780 tumors (22-25 g; Charles River Laboratories) received intravenous injection of dual-radiolabeled copolymer-EPI conjugates (1 mg, $20 \mu \mathrm{Ci}$ per mouse). At $48 \mathrm{~h}$ and $144 \mathrm{~h}$ after administration, the mice were sacrificed. Various tissues (heart, liver, spleen, lung, stomach, intestine, muscle, bone, brain and tumor) were harvested, weighed, and counted for radioactivity with Gamma Counter (Packard) with the aforementioned ${ }^{111} \mathrm{In} / /^{125} \mathrm{I}$ dual-isotope protocol. Uptake of the conjugate was calculated as the percentage of the injected dose per gram of tissue (\% ID/g). Data are presented as mean \pm standard deviation $(n=5)$. 


\subsubsection{Statistics}

Statistical analyses were done using a two-tailed unpaired Student's t-test, with $p$ values of $<0.01$ indicating statistically significant differences.

\section{RESULTS AND DISCUSSION}

\subsection{Design and synthesis of dual-radiolabeled HPMA copolymer-EPI conjugates}

HPMA-based polymer drug conjugates have been investigated for decades; most of studies focused on the treatment of solid tumors. It has been demonstrated in preclinical studies that polymer-drug conjugates have numerous advantages compared to current marketed chemotherapeutical agents as a result of enhanced permeability and retention (EPR) effect. To accelerate the translation process from bench to bed, we propose a general approach to the synthesis of dual-labeled polymer-drug conjugates; one radiolabel is bound to polymeric carrier and the other is attached to drug (or model drug), in order to concurrently investigate two different molecular functions via multiple imaging modalities. As depicted in Scheme 1, the key component in our design is an azide-containing drug monomer MAGFLG-Abu( $\left.\mathrm{N}_{3}\right)$-Drug. By copolymerization of MA-GFLG-Abu( $\left.\mathrm{N}_{3}\right)$-Drug with HPMA and APMA, a heterobifunctional polymer precursor will be obtained. The pendant amino groups can be used to incorporate a fluorescence dye containing $\mathrm{N}$-hydroxysuccinimide $(\mathrm{NHS})$ ester reactive group to polymer backbone. The second fluorophore will be introduced via azide-alkyne click reaction that has high specificity. The resulting dual-fluorophore labeled conjugates could be used for optical imaging studies such as bioluminescence imaging or fluorescence tomography (FMT). This approach can also be used to synthesize a dual-radiolabeled polymer-drug conjugate for PET/CT imaging or pharmacokinetics and biodistribution studies due to high sensitivity of radionuclides. For example, Bolton-Hunter reagent can be used to modify amino group to tyrosine-like structure for backbone iodination, while copper-free approach could be applied for attachment of a chelator such as DTPA followed by incorporation of a radiometal ion.

In this study, we focused on dual-radiolabeling strategy. First generation polymer conjugate PDTPA-EPI(Tyr) ( $\mathrm{Mw}<50 \mathrm{kDa}$, i.e. below the renal threshold, see SI Fig. S6) and backbone degradable HPMA copolymer-EPI conjugates 2P-DTPA-EPI(Tyr) (diblock with $\mathrm{Mw}>50 \mathrm{kDa}$; above the renal threshold) were synthesized to evaluate the impact of molecular weight and degradability of the conjugate on its fate in the organism. We slightly modified the synthetic approach in Scheme 1: Instead of using Bolton-Hunter reagent, we attached $p$-SCN-Bn-DTPA to the pendant amino group on the polymer backbone, while a tyrosine moiety was coupled with $\mathrm{N}_{3}$ group via $\mathrm{Cu}(\mathrm{I})$ assisted alkyne-azide click reaction. To further investigate how radiolabel type impacts properties of the conjugates, 2P-TyrEPI(DTPA) containing an ${ }^{125}$ l labeling site on the polymer backbone and an ${ }^{111}$ In labeling site at the modified EPI was synthesized. The overall synthetic process for $2^{\text {nd }}$ generation conjugates is described in Scheme 2, more detailed synthetic schemes including monomers, RAFT agent and $1^{\text {st }}$ generation conjugate are listed in Supplementary Information. The conjugates to be evaluated were summarized in Table 1 (I, III and V). They were radiolabeled by ${ }^{125}$ and ${ }^{111}$ In consecutively, yielded dual-labeled products II, IV and VI for pharmacokinetic and biodistribution studies. 


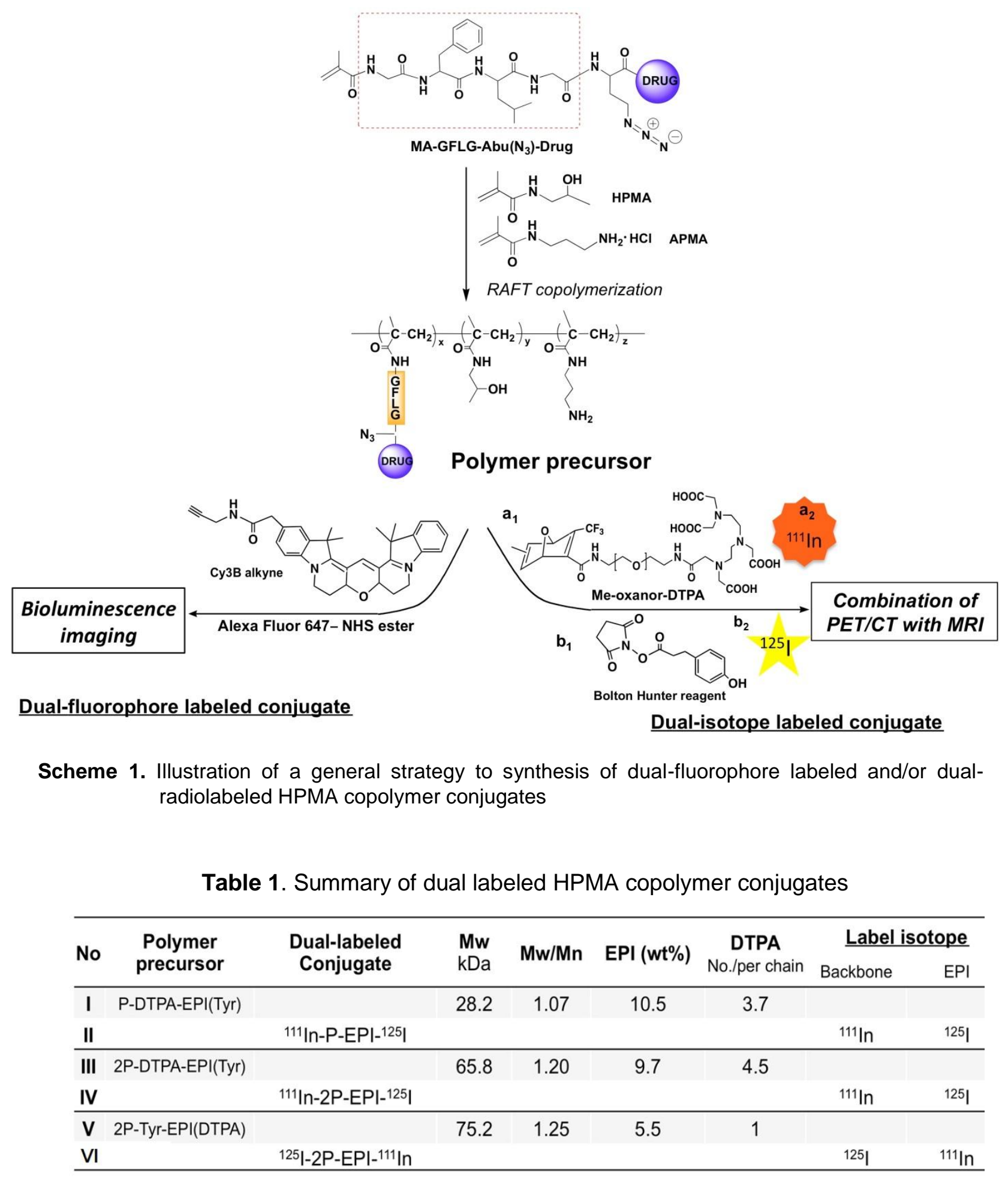


A
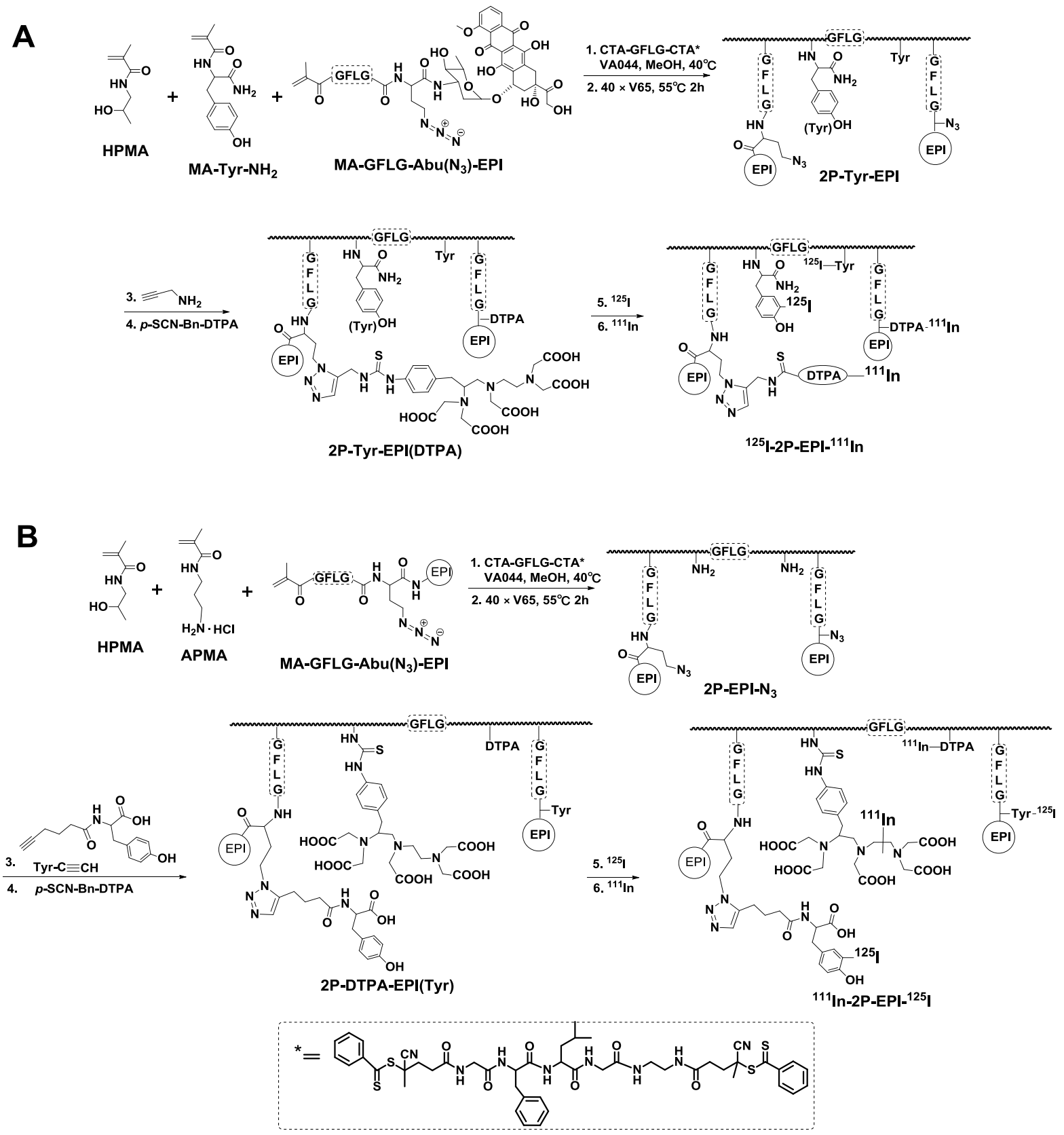

Scheme 2. Synthesis of HPMA copolymer-EPI conjugates and dual-radiolabeling strategy. (A) Synthesis of $2^{\text {nd }}$ generation conjugate 2P-Tyr-EPI(DTPA) by RAFT copolymerization of MA-GFLG-Abu( $\left.\mathrm{N}_{3}\right)$-EPI with HPMA and MA-Tyr- $\mathrm{NH}_{2}$ using a cleavable diarm RAFT agent CTA-GLFG-CTA. Propargylamine was coupled with $\mathrm{N}_{3}$ group and chelator DTPA was attached for drug labeling with ${ }^{111} \mathrm{In}$. The polymer precursor was consecutively labeled with ${ }^{125} \mathrm{I}$ (polymer backbone) and ${ }^{111} \mathrm{In}$ (EPI). (B) Synthesis of $2^{\text {nd }}$-generation conjugate 2P-DTPA-EPI(Tyr) by copolymerization of MA-GFLG-Abu( $\left(\mathrm{N}_{3}\right)$-EPI with HPMA and APMA. Tyrosine residue was incorporated via $\mathrm{Cu}(\mathrm{I})$ assisted alkyne-azide click reaction. DTPA was attached to polymer backbone via pendent amino group modification with $p$-SCN-Bn-DTPA. The polymer precursor was then labeled with ${ }^{125} \mathrm{I}$ and ${ }^{111} \mathrm{In}$, consecutively. 


\subsection{Enzymatic cleavage study of HPMA copolymer-EPI conjugates}

As a payload tracer, the cleavability of modified EPI is important for interpretation of pharmacokinetic profile and biodistribution result. In the ideal case, the radioisotope will be bound to the drug molecule and cleaved together without change of drug release rate. If the label and drug separate, then the radioactivity level will not be relevant to the drug concentration. To examine whether the modified EPI keeps intact when it is cleaved in the lysosomes, we synthesized model conjugate P$\mathrm{EPI}(\mathrm{Tyr})$ and determined its stability in the presence of lysosome enzyme. Unmodified P-EPI was synthesized and served as control. Unlike the synthetic procedure described above (Scheme 2B), in PEPI(Tyr), the tyrosine moiety was first incorporated to the monomer MA-GFLG-Abu(N3)-EPI via click reaction, then purified and polymerized to ensure there is no unmodified EPI left. The structure and physicochemical characterization of two conjugates are listed in Table 2 and Fig. S10.

Table 2 Model conjugates for enzyme cleavage

\begin{tabular}{llllll}
\hline Conjugate & $\mathrm{Mw}, \mathrm{kDa}$ & $\mathrm{Mw} / \mathrm{Mn}$ & $\mathrm{EPI}(\mathrm{wt} \%)$ \\
\hline P-EPI (Tyr) & & & & & \\
\hline
\end{tabular}

For cleavage, we have chosen to use Tritosomes, a mixture of lysosomal enzymes isolated from liver of rats, to mimic in vivo enzyme environment. The conjugates containing $300 \mathrm{nmol}$ equivalent EPI were incubated with $0.48 \mathrm{~mL}$ Tritosomes at $37^{\circ} \mathrm{C}$ for $48 \mathrm{~h}$. Hydrolysis rate was monitored using HPLC. The results are shown in Fig. 1

When incubated with Tritosomes, HPLC showed that the wide peak of conjugate P-EPI was decreased with incubation time, while free EPI peak emerged. Eventually conjugate was not detectable, indicating EPI was released from P-EPI gradually, and almost 100\% release was reached within $48 \mathrm{~h}$. In contrast, a new unknown peak occurred in P-EPI(Tyr) and increased slowly with incubation time (Fig. 1B). During $48 \mathrm{~h}$ incubation, a very small EPI peak also emerged. The fractions were collected and determined using MALDI-TOF mass spectroscopy. The result suggested that the cleavage mainly yielded two products, glycine-EPI-Tyr ([G-EPI-Tyr+Na $]^{+}$, 1024.39) and EPI-Tyr ([EPI-Tyr+Na $\left.]^{+}, 967.37\right)$ (Fig. 1C,D). The free drug EPI was only $2.5 \%$ compared to the modified EPI.

These findings are agreement with our previous studies. It was well established that the most important enzyme in the lysosomal compartment (and in Tritosomes) in the cleavage of oligopeptide sequences attached to HPMA copolymers is Cathepsin B. Other enzymes participate in the cleavage to a lesser extent [9,53-54]. Cathepsin B (EC 3.4.22.1) is an important lysosomal enzyme active in the 
degradation of internalized proteins and peptides. It is a cysteine protease and its active site accommodates at least four amino acid residues towards the $\mathrm{NH}_{2}$ end of the substrate (positions $\mathrm{P} 4$ P1; subsites S1 - S4; nomenclature of Schechter-Berger [55]) and two amino acid residues toward the $\mathrm{COOH}$ end of the substrate (positions P1' and P2'). The GFLG sequence was designed to match the specificity of cathepsin B in the lysosomal compartment [53] and is now widely used as an attachment/release moiety in the design of lysosomotropic nanomedicines [9].
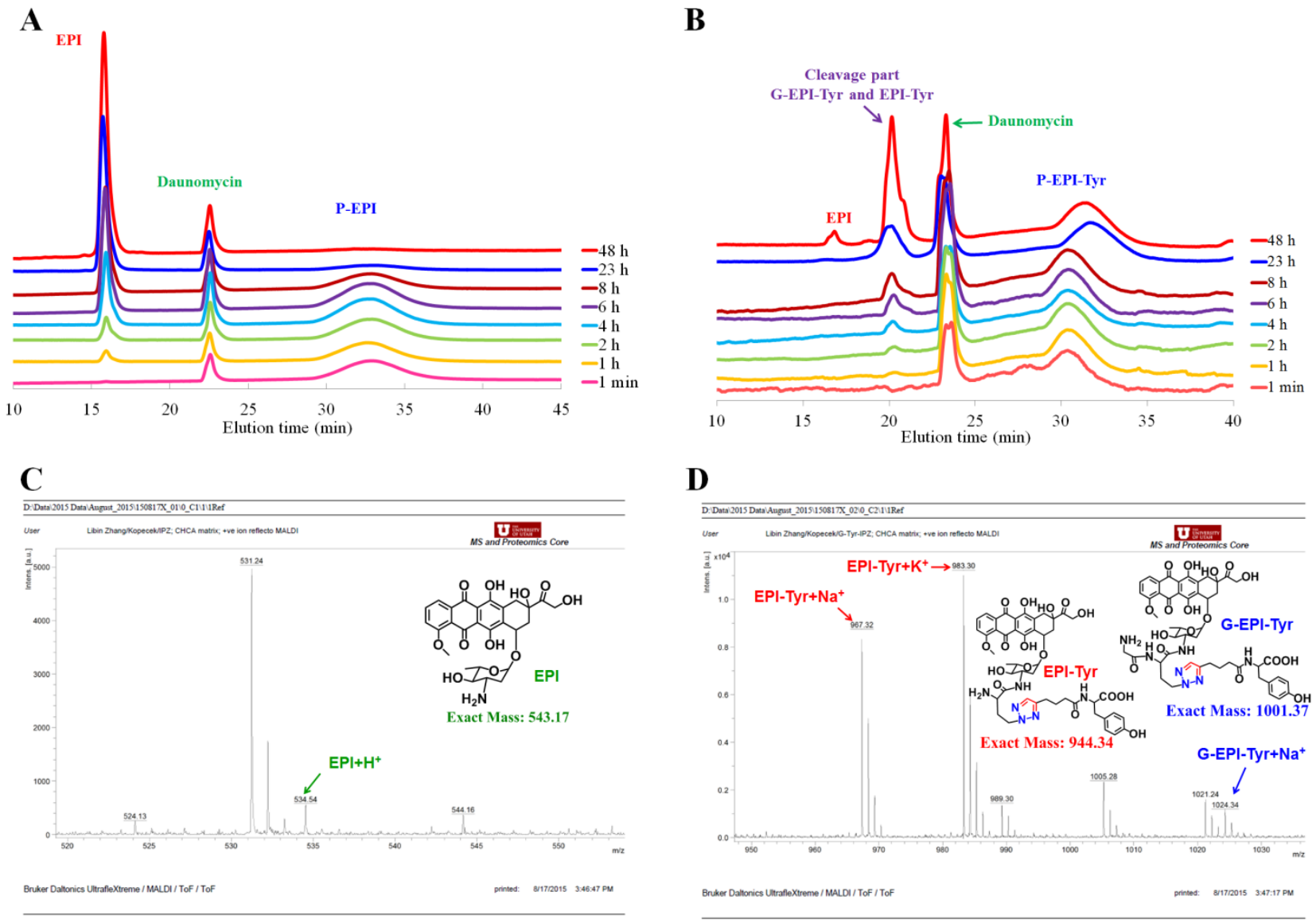

Fig. 1. Tritosomes cleavage of $P$-EPI and P-EPI(Tyr). HPLC analysis of P-EPI $(A)$ and $P$-EPI(Tyr) (B) at different time intervals (1 $\min , 1,2,4,6,8,23$, and 48 h). Daunomycin was used as internal standard. MALDI-TOF-MS analysis of cleaved products from P-EPI(Tyr) (C,D).

Comparison of cleavage of polymer-drug conjugates containing the GFLG spacer revealed that other enzymes participate in the cleavage within the lysosomal compartment [54]. In addition, the rate of enzymatically-catalyzed hydrolysis depends on the structure of the ligand (drug) bound to the GFLG sequence. Since the GFLG spacer aligns into S4-S1 subsites of cathepsin B, the different rate of drug release depends on the fit of the drug (ligand) into subsites S1' and S2' [56]. The formation of G-EPITyr indicates that part of the substrate bound to the active site with phenylalanine in the (preferred [57]) P2 position. Probably, based on the bulkiness of EPI-Tyr, the cleavage of G-EPI-Tyr by cathepsin B 
occurred first and other enzymes present in Tritosomes subsequently cleaved the bond between

glycine and EPI. In addition, the results indicated that the bond between the tyrosine moiety and EPI was stable since only a very small amount of free EPI was detected.

The two different dual label $2^{\text {nd }}$-generation conjugates, 2P-Tyr-EPI(DTPA) and 2P-DTPA$\mathrm{EPI}(\mathrm{Tyr})$, were also cleaved with Tritosomes. 2PDTPA-EPI(Tyr) showed similar cleavage pattern to P-EPI(Tyr), mainly yielded EPI(Tyr) with little G$\mathrm{EPI}(\mathrm{Tyr})$ and tiny free EPI. However, 2P-TyrEPI(DTPA) resulted in more complicated cleavage products, as shown in MALDI-TOF-MS (Fig. 2C). It revealed the presence of LG-EPI(DTPA), G-EPIDTPA and EPI-DTPA. This indicates the due to the size of EPI-DTPA the substrate aligns to the cathepsin B active site with GFLG in subsites S2 S2'. Other lysosomal enzymes participate in the cleavage of LG-EPI(DTPA) to G-EPI(DTPA) and EPI(DTPA) (Table 3).

The results of enzymatic cleavage of the conjugates clearly indicate the impact of the steric hindrance of the bulky payload on the S1'-P1' and S2'-P2" interactions. This needs to be taken into account when interpreting biodistribution data.
A
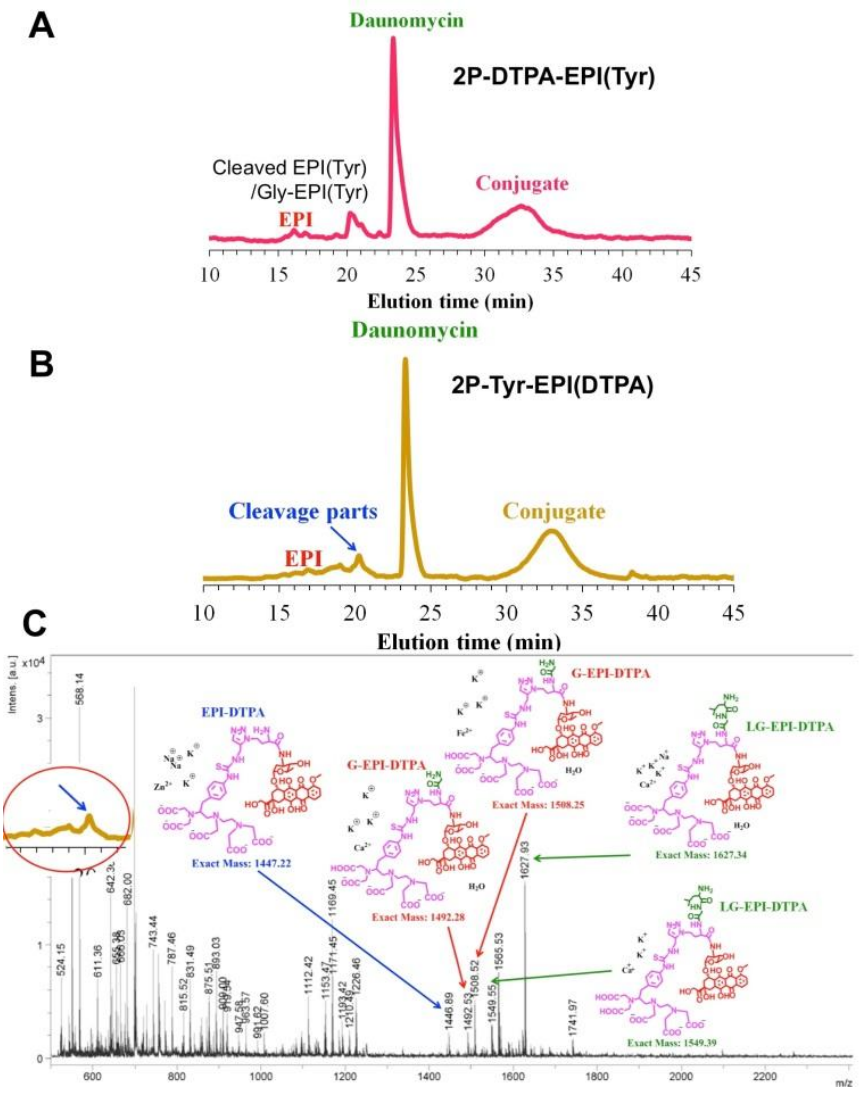

Fig. 2. Tritosomes cleavage of $2^{\text {nd }}$-generation HPMA copolymer-EPI conjugates. HPLC analysis of $2 \mathrm{P}$ DTPA-EPI(Tyr) (A) and 2P-Tyr-EPI(DTPA) (B) following incubation with Tritosomes for $45 \mathrm{~h}$. MALDITOF-MS analysis of cleaved products from 2P-TyrEPI(DTPA) (C).

Table 3. Structure of the conjugates and enzyme cleavage products

2P-Tyr-EPI(DTPA) Side-chain cleaved products




\subsection{Pharmacokinetics and biodistribution study of dual-radiolabeled copolymer-PEI conjugates}

Dual-labeled products II, IV and VI (see Table 1) were administered to nude mice via tail veins for pharmacokinetics and biodistribution studies. The dual-radiolabel strategy allowed to simultaneously track the fate of the payload (EPI- ${ }^{125}$ I or EPI- $\left.{ }^{111} \mathrm{In}\right)$ and of the polymeric carriers $\left({ }^{111} \mathrm{In}-\mathrm{P} /{ }^{111} \mathrm{In}-2 \mathrm{P}\right.$ or ${ }^{125} \mathrm{I}$ $2 \mathrm{P})$. Fig. $3 \mathrm{~A}$ shows blood radioactivity-time profiles of $1^{\text {st }}$ and $2^{\text {nd }}$ generation conjugates in which polymer backbone was labeled with ${ }^{111}$ In and drug with ${ }^{125}$. For each conjugate, both ${ }^{111}$ In and ${ }^{125}$ I showed very similar pattern indicating the linker GFLG between drug and polymeric carrier is stable in blood circulation during transport. Moreover, it clearly demonstrated the superior property of $2^{\text {nd }}$ generation conjugate $\left({ }^{111} \mathrm{In}-2 \mathrm{P}-\mathrm{EPI}-{ }^{125} \mathrm{I}\right)$ with higher molecular weight on enhanced plasma concentration and elongation of circulation time as compared with ${ }^{111} \mathrm{In}-\mathrm{P}-\mathrm{EPI}-{ }^{125} \mathrm{I}$. Consequently, the tumor-uptake of ${ }^{111}$ In-2P-EPI- ${ }^{125}$ I was $2-3$ folds greater than ${ }^{111}$ In-P-EPI- ${ }^{125}$ as illustrated in Fig. $3 \mathrm{~B}$.
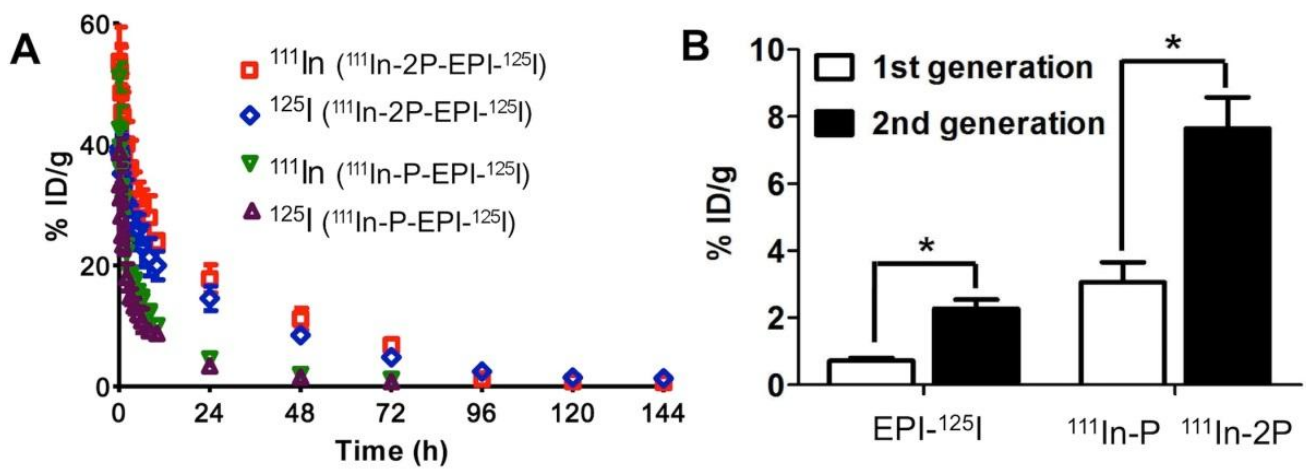

Fig. 3. Comparison of pharmacokinetic profiles and tumor-uptake of dual-labeled $1^{\text {st }}$ generation conjugate ${ }^{111}$ In-PEPI- ${ }^{125}$ and $2^{\text {nd }}$ generation conjugate ${ }^{111}$ In-2P-EPI- ${ }^{125}$ I in nu/nu mice. (A) Blood activity-time profiles of ${ }^{111}$ Inlabeled polymer carriers and ${ }^{125} \mathrm{I}$ labeled drug EPI in mice. (B) Radioactivity level in tumors for the mice bearing subcutaneous A2780 xenografts $48 \mathrm{~h}$ after intravenous injection of dual radiolabeled conjugates. Here ${ }^{111}$ In corresponds to polymer carrier $\left(1^{\text {st }}\right.$ generation $\mathrm{P}$ - and $2^{\text {nd }}$ generation $2 \mathrm{P}-$ ) and ${ }^{125} \mathrm{I}$ to drug EPI, respectively. The data represent the mean radioactivity expressed as a percentage of the injected dose per gram of blood $(n=5)$. $p$ $<0.001$

This observation provides a direct proof that backbone degradable diblock HPMA copolymer carriers can more effectively deliver drugs to the tumor, resulting in the improvement of the treatment efficacy and decrease of non-specific adverse effect, in agreement with our previous report [28].
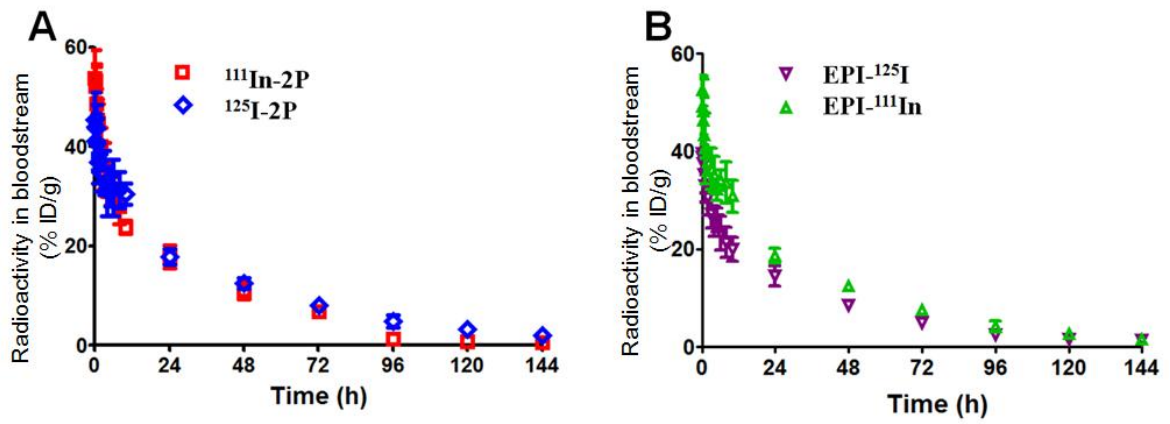

Fig. 4 Effect of radiolabeling strategy on pharmacokinetic profiles of the polymer carrier $(A)$ and payload (EPI) (B) of backbone degradable diblock HPMA copolymer-EPI conjugates in tumor-bearing nu/nu mice. 2P-DTPA$\mathrm{EPI}(\mathrm{Tyr})$ with average Mw $66 \mathrm{kDa}$ and 2P-Tyr-EPI(DTPA) with Mw $75 \mathrm{kDa}$ were used. Data obtained using the 
radioactivity count method are plotted as percentage of injected dose per gram of tissue $(\% / D / g)$. All data are expressed as mean \pm standard deviation $(n=5)$.

Figure 4 shows the blood radioactivity-time profiles of different isotope-labeled polymer carriers $(A)$ and payload (modified EPI) (B). Conjugate IV has similar Mw as conjugate VI. Their backbones were labeled with ${ }^{111}$ In and ${ }^{125} \mathrm{I}$, respectively, and side chain drug EPI was labeled with ${ }^{125} \mathrm{I}$ and ${ }^{111} \mathrm{In}$; similar pharmacokinetics for polymer carrier and for payload was observed. Combined with results from Fig. 3, this suggests that for water-soluble polymer-drug conjugates, the molecular weight plays a decisive role on its circulation time and body clearance, while side-chain modification has a minor impact. This result also suggests that the modification of EPI structure does not influence the PK of the conjugate.

Pharmacokinetic parameters are summarized in Table 4 . Both $2^{\text {nd }}$ generation conjugates, ${ }^{111} \operatorname{In}-2 \mathrm{P}$ EPI- ${ }^{125} \mathrm{I}$ and ${ }^{125} \mathrm{I}-2 \mathrm{P}-\mathrm{EPI}-{ }^{111} \mathrm{In}$, showed similar half-life, which was much longer than that of the $1^{\text {st }}$ generation conjugate ${ }^{111} \mathrm{In}$-P-EPI- ${ }^{125}$. For example, the terminal half-lives of payload EPI(Tyr) ${ }^{125}$ and EPI(DTPA $)^{111} \mathrm{In}$ in $2^{\text {nd }}$ generation conjugates were $29.79 \mathrm{~h}$ and $28.40 \mathrm{~h}$, respectively; they are very close to the terminal half-lives of polymeric carriers ${ }^{111} \mathrm{In}-2 \mathrm{P}(31.52 \mathrm{~h})$ and ${ }^{125} \mathrm{I}-2 \mathrm{P}(31.11 \mathrm{~h})$. However, terminal half-life of payload EPI(Tyr $)^{125} \mathrm{I}$ in $1^{\text {st }}$ generation conjugates and the polymeric carrier ${ }^{111} \mathrm{In}-\mathrm{P}$ were $9.63 \mathrm{~h}$ and $9.20 \mathrm{~h}$, respectively. The total area under the blood concentration versus time curve (AUC) of ${ }^{111} \mathrm{In}-2 \mathrm{P}-\mathrm{EPI}-{ }^{125} \mathrm{I}\left(1135 \%\right.$ injected dose per $\mathrm{mL}(\mathrm{ID} / \mathrm{mL})$ for ${ }^{125} \mathrm{I}$ and $1474 \% \mathrm{ID} / \mathrm{mL}$ for $\left.{ }^{111} \mathrm{In}\right)$ and of ${ }^{125} \mathrm{I}-2 \mathrm{P}$-EPI- ${ }^{111} \mathrm{In}\left(1604 \% \mathrm{ID} / \mathrm{mL}\right.$ for ${ }^{111} \mathrm{In}$ and $1628 \% \mathrm{ID} / \mathrm{mL}$ for $\left.{ }^{125} \mathrm{I}\right)$ were significantly higher than that of ${ }^{111} \mathrm{In}$-P-EPI- ${ }^{125} \mathrm{I}\left(261 \% \mathrm{ID} / \mathrm{mL}\right.$ for ${ }^{125} \mathrm{I}$ and $324 \% \mathrm{ID} / \mathrm{mL}$ for $\left.{ }^{111} \mathrm{In}\right)(\mathrm{P}<0.001)$ (Table 4). Comparing with $1^{\text {st }}$ generation conjugate ${ }^{111} \mathrm{In}$-P-EPI- ${ }^{125} \mathrm{I}$, the increased exposure of $2^{\text {nd }}$ generation conjugates ${ }^{111} \mathrm{In}-2 \mathrm{P}$ EPI- ${ }^{125} \mathrm{I}$ and ${ }^{125} \mathrm{I}-2 \mathrm{P}-\mathrm{EPI}-{ }^{111} \mathrm{In}$ resulted mainly from a significantly slower mean systemic clearance (CL) $(P<0.001)$

Table 4. Comparison of pharmacokinetic parameters of dual-labeled $\left({ }^{125} \mathrm{I}\right.$ - and ${ }^{111} \mathrm{In}$-based $) 1^{\text {st }}$ generation conjugate and $2^{\text {nd }}$ generation conjugates in mice

\begin{tabular}{|c|c|c|c|c|c|c|}
\hline \multirow{3}{*}{$\begin{array}{l}\text { Conjugate } \\
\text { Component }\end{array}$} & \multirow{2}{*}{\multicolumn{2}{|c|}{$\begin{array}{l}\text { 1st Generation } \\
{ }^{111} \mid \text { n-P-EPI-125| }\end{array}$}} & \multicolumn{4}{|c|}{ 2nd Generation } \\
\hline & & & \multicolumn{2}{|c|}{${ }^{111}|n-2 P-E P|-125 \mid$} & \multicolumn{2}{|c|}{${ }^{125}$ |-2P-EPI-111/n } \\
\hline & EPI(Tyr)-125| & $P(D T P A)^{111} / n$ & EPI(Tyr) $)^{125}$ & $2 \mathrm{P}(\mathrm{DTPA})^{111} \mathrm{ln}$ & EPI(DTPA) ${ }^{111}$ In & $2 \mathrm{P}(\mathrm{Tyr})^{125 \mathrm{I}}$ \\
\hline $\mathrm{T}_{1 / 2, \alpha}(\mathrm{h})$ & $0.57 \pm 0.07$ & $0.50 \pm 0.08$ & $1.51 \pm 0.20$ & $1.58 \pm 0.19$ & $0.49 \pm 0.13$ & $0.47 \pm 0.16$ \\
\hline $\mathrm{T}_{1 / 2, \beta}(\mathrm{h})$ & $9.63 \pm 1.47$ & $9.20 \pm 1.68$ & $29.79 \pm 1.62$ & $31.52 \pm 2.01$ & $28.40 \pm 2.03$ & $31.11 \pm 2.19$ \\
\hline $\begin{array}{c}\text { AUC } \\
\text { (\% ID h/mL) }\end{array}$ & $260.72 \pm 24.64$ & $324.25 \pm 36.98$ & $1135.00 \pm 43.81$ & $1473.97 \pm 65.83$ & $1604.36 \pm 95.44$ & $1628.32 \pm 97.28$ \\
\hline $\mathrm{CL}(\mathrm{mL} / \mathrm{h})$ & $0.38 \pm 0.03$ & $0.30 \pm 0.03$ & $0.08 \pm 0.003$ & $0.06 \pm 0.003$ & $0.06 \pm 0.003$ & $0.06 \pm 0.004$ \\
\hline MRT (h) & $13.01 \pm 1.96$ & $12.46 \pm 2.25$ & $41.85 \pm 2.21$ & $43.95 \pm 2.73$ & $40.71 \pm 2.89$ & $44.69 \pm 3.15$ \\
\hline Vss (mL) & $4.99 \pm 0.31$ & $3.84 \pm 0.29$ & $3.68 \pm 0.08$ & $2.98 \pm 0.08$ & $2.53 \pm 0.05$ & $2.74 \pm 0.06$ \\
\hline
\end{tabular}

$\mathrm{T}_{1 / 2, \alpha}=$ initial half-life; $\mathrm{T}_{1 / 2, \beta}=$ terminal half-life; $\mathrm{AUC}=$ total area under the blood concentration versus time curve; \%ID = percentage of injected dose; $C L=$ total body clearance; $M R T=$ mean residence 
time; Vss = steady-state volume of distribution. Data are presented as mean \pm standard deviation $(\mathrm{n}=5)$.

We also analyzed biodistribution of payload and carrier in female nude mice bearing A2780 human ovarian carcinoma. A high and lasting radioactivity level of polymer carrier labeled with ${ }^{111} \operatorname{In}\left({ }^{111} \operatorname{In}-2 \mathrm{P}\right)$ in kidney was observed, in contrast to the polymer carrier labeled with ${ }^{125} \mathrm{I}\left({ }^{125} \mathrm{I}-2 \mathrm{P}\right.$, Figs. 5A \& 5B). Two phenomena may contribute to this observation: First, the incorporation of chelator DTPA for ${ }^{111}$ In labeling induces negative charges to the polymer carrier; it has been observed that this enhances the accumulation in the cortex and renal tubules after intravenous administration in mice $[32,58,59]$. Second, it is more likely due to ${ }^{111}$ In strong kidney accumulation and slow clearance as noted by others [60-62]. Other than ${ }^{111} \mathrm{In}-2 \mathrm{P}$ in kidney, at $48 \mathrm{~h}$ after intravenous injection of $2^{\text {nd }}$ generation conjugates, the highest concentration of conjugates (both payload EPI and polymer carrier) was still in blood stream, indicating the advantage of high molecular weight conjugates. Until $144 \mathrm{~h}$, the concentrations of polymer carrier and payload EPI(DTPA) $)^{111}$ In in tumor were clearly higher than the levels in the normal organs except liver, and spleen, demonstrating the targeting ability of polymer conjugates to tumor (Figs. 5A \& 5B). However, EPI(Tyr) ${ }^{125}$ I showed lower uptake than EPI(DTPA $)^{111}$ In in major organs and tumor at both $48 \mathrm{~h}$ and $144 \mathrm{~h}$ (Figs. 5A \& 5B); at same time points payload EPI(DTPA) ${ }^{111}$ In showed similar uptake as polymeric carrier ${ }^{125} \mathrm{I}-2 \mathrm{P}$ in major organs and tumor. There are several factors that may contribute to this result: different drug release rates resulting from steric hindrance of EPI modification, and lower retention of radioiodine. It has been reported that after endocytosis and proteolytic degradation in lysosomes, the iodine-labeled conjugates generate iodotyrosine, which is rapidly excreted from cells and shows poor retention in normal organs and tumors [63,64]. In addition, radioiodide could be liberated from iodotyrosine by dehalogenase enzymes and rapidly sequestered by thyroid [32]. Future in vivo experiments using D-amino acids could evaluate the importance of this pathway [65-67].

We compared the tumor-to-tissue uptake ratios of payload and polymeric carriers and found that the tumor-to-tissue uptake ratios of both radionuclides were similar (Fig. S15). The tumor-to-tissue uptake ratios of $2^{\text {nd }}$ generation conjugates were higher than that of $1^{\text {st }}$ generation conjugate for both payloads and polymeric carriers.

A

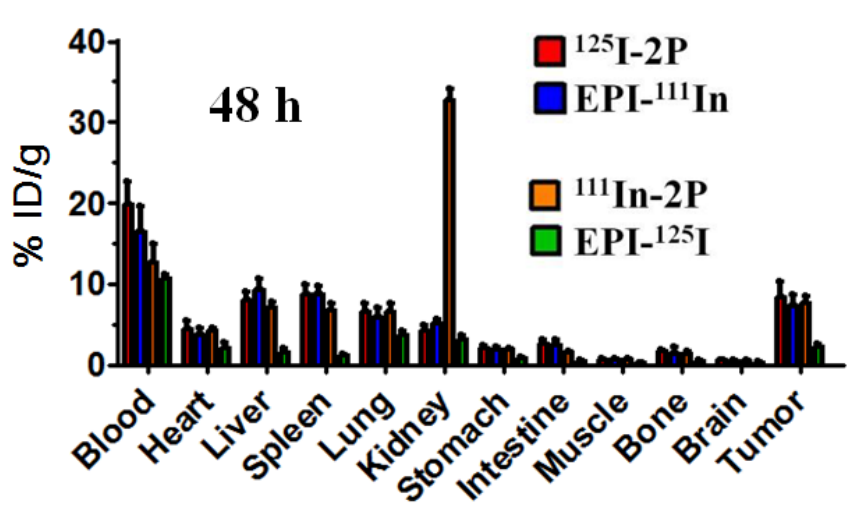

B

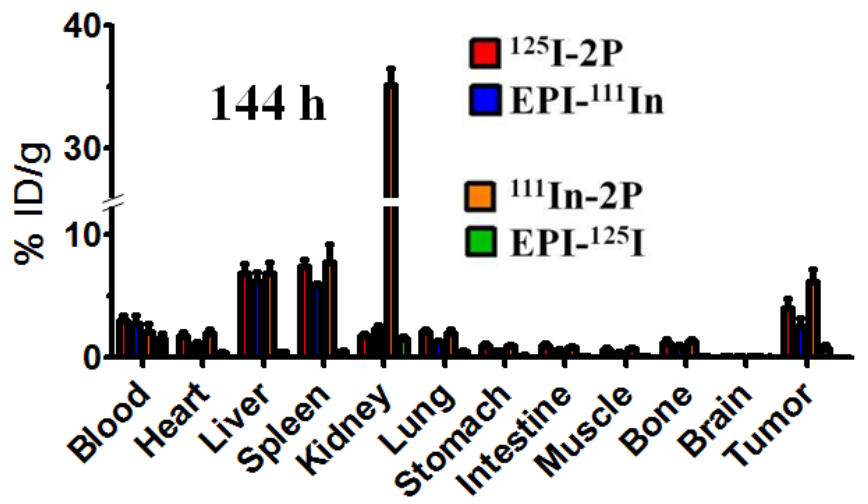

Fig. 5. Effect of radiolabeling strategy on biodistribution of the polymer carrier and payload (EPI) of backbone degradable diblock HPMA copolymer-EPI conjugates in tumor-bearing mice at $48 \mathrm{~h}(\mathbf{A})$ and $144 \mathrm{~h}$ (B) after intravenous administration. Data obtained using the radioactivity count method are plotted as percentage of 1 injected dose per gram of tissue $(\% / D / g)$. All data are expressed as mean \pm standard deviation $(n=5)$. 
Taking together with the results we previously obtained [26] and other literatures [33,68-69], pharmacokinetics and biodistribution results indicated: 1) GFLG linker between payload and polymeric carrier remained stable in the bloodstream during transport. 2) After internalization via endocytosis and localization in the lysosomes, the payload EPI(Tyr $)^{125}$ of ${ }^{111} \mathrm{In}-2 \mathrm{P}-\mathrm{EPI}{ }^{-125}$ I was slowly cleaved from the polymeric carrier; its excretion from cells resulted in low retention in normal organs and tumor. 3 ) Payload EPI(DTPA) ${ }^{111}$ In of ${ }^{125} \mathrm{I}-2 \mathrm{P}-\mathrm{EPI}{ }^{111}$ In was cleaved more slowly from the carrier compared to payload EPI(Tyr) ${ }^{125}$. 4) Different radiolabel designs does not influence tumor-to-tissue uptake ratios of payload and polymeric carrier. 5) The pharmacokinetics of an unlabeled conjugate that would be used as the macromolecular therapeutics should be similar with that of labeled conjugate, but the drug retention of unlabeled conjugate would be shorter as a result of faster cleavage of payload from the GFLG spacer.

\section{CONCLUSIONS}

We developed a unique and general route to synthesize dual-isotope labeled HPMA copolymer-EPI conjugates for evaluation of the fate of conjugates in animal bodies. Tritosomes hydrolysis study demonstrated that the cleavage site and hydrolysis rate depend on the structure of substrate-it can be cleaved within the GFLG linker, or between the linker and payload. The bulky group used for drug modification (EPI(Tyr) or EPI(DTPA)) may cause steric hindrance on the formation of the enzymesubstrate complex, therefore slow down the drug release. Pharmacokinetics and biodistribution study illustrated that the labeling by viable radionuclides does not change the blood-clearance behavior, but may have impact on biodistribution. lodine-based biodistribution may differ significantly from that obtained using a radiometal label. The tumor-to-tissue uptake ratios of both radionuclides were similar, indicating that drug-labeling strategy does not affect the tumor targeting ability of HPMA copolymer conjugates. We anticipate that this practical and efficient dual radiolabeling method offers a reliable method to study different polymer-based water-soluble drug delivery systems. Numerous anticancer drugs, including doxorubicin, paclitaxel, and gemcitabine bound to carriers of different structures (PEG, HPMA, poly(amino acid)s, polyacetals, polyamidoamines, etc) could be evaluated and the mechanism of their action revealed. The double-labeled conjugates have a potential in dual-isotope imaging, radiochemotherapy, and preclinical evaluation and optimization of nanoconjugates.

\section{Acknowledgements}

The research was supported in part by Department of Defense Grant W81XWH-13-1-0160 and NIH grant CA156933.

\section{References}

[1] H. Maeda, Tumor-selective delivery of macromolecular drugs via the EPR effect: Background and future prospects, Bioconjugate Chem. 21 (2010) 797-802.

[2] Y. Zhou, J. Kopeček, Biological rationale for the design of polymeric anti-cancer nanomedicines, J. Drug Target. 21 (2013) 1-26. 
[3] R. Duncan, The dawning era of polymer therapeutics, Nat. Rev. Drug Discov. 2 (2003) 347-360.

[4] J. Yang, J. Kopeček, Design of smart polymer-based nanomedicines, J. Control. Release (2015), http://dx.doi.org/10.1016/j.jconrel.2015.10.003.

[5] J.M. Harris, R.B. Chess, Effect of pegylation on pharmaceuticals, Nat. Rev. Drug Discov. 2 (2003) 214-221.

[6] G. Pasut, F.M. Veronese, PEG conjugates in clinical development or use as anticancer agents: an overview, Adv. Drug Deliv. Rev. 61 (2009) 1177-1188.

[7] K. Ulbrich, V. Šubr, Structural and chemical aspects of HPMA copolymers as drug carriers, Adv. Drug Deliv. Rev. 62 (2010) 150-166.

[8] R. Duncan, L.W. Seymour, K.B. O'Hare, P.A. Flanagan, S. Wedge, I.C. Hume, K. Ulbrich, J. Strohalm, V. Šubr, F. Spreafico, M. Grandi, M. Ripamonti, M. Farao, A. Suarato, Preclinical evaluation of polymer-bound doxorubicin, J. Control. Release 19 (1992) 331-346.

[9] J. Kopeček, P. Kopečková, HPMA copolymers: Origins, early developments, present, and future, Adv. Drug Deliv. Rev. 62 (2010) 122-149.

[10] B. Říhová, M. Kovář, Immunogenicity and immunomodulatory properties of HPMA-based polymers, Adv. Drug Deliv. Rev. 62 (2010) 184-191.

[11] J.-G. Shiah, Y. Sun, P. Kopečková, C.M. Peterson, R.C. Straight, J. Kopeček, Combination chemotherapy and photodynamic therapy of targetable $\mathrm{N}$-(2-hydroxypropyl)methacrylamide copolymer - doxorubicin/mesochlorin $\mathrm{e}_{6}-$ OV-TL16 antibody immunoconjugates, J. Control. Release 74 (2001) 249-253.

[12] L. Paz-Ares, H. Ross, M. O’Brien, A. Riviere, U. Gatzemeier, J. Von Pawel, E. Kaukel, L Freitag, W. Digel, H. Bischoff, R. Garcia-Campello, N. lannotti, P. Reiterer, I. Bover, J. Prendiville, A.J. Eisenfeld, F.B. Oldham, B. Bandstra, J.W. Singer, P. Bonomi, Phase III trial comparing paclitaxel poliglumex vs docetaxel in the second-line treatment of non-small-cell lung cancer, Br. J. Cancer 98 (2008) 1608-1613.

[13] T.X. Viegas, M.D. Bentley, J.M. Harris, Z. Fang, K. Yoon, B. Dizman, R. Weimer, A. Mero, G. Pasut, F.M. Veronese, Polyoxazolines: chemistry, properties, and applications in drug delivery, Bioconjug. Chem. 22 (2011) 976-986.

[14] H. Ding, S. Inoue, A. V. Ljubimov, R. Patil, J. Portilla-Arias, J. Hu, B. Konda, K. A. Wawrowsky, M. Fujita, N. Karabalin, T. Sasaki, K.L. Black, E. Holler, J.Y. Ljubimova, Inhibition of brain tumor growth by intravenous poly( $\beta$-L-malic acid) nanobioconjugate with $\mathrm{pH}$-dependent drug release, Proc. Natl. Acad. Sci. U. S. A. 107 (2010) 18143-18148.

[15] A.S. Abu Lila, H. Kiwada, T. Ishida, The accelerated blood clearance (ABC) phenomenon: Clinical challenge and approaches to manage, J. Control. Release 172 (2013) 38-47.

[16] M. Barz, R. Luxenhofer, R. Zentel, M.J. Vicent, Overcoming the PEG-addiction: well-defined alternatives to PEG, from structure-property relationships to better defined therapeutics, Polym. Chem. 2 (2011) 1900-1918.

[17] B. S. Tucker and B. S. Sumerlin, Poly(N-(2-hydroxypropyl)methacrylamide)-based nanotherapeutics, Polym. Chem. 5 (2014) 1566-1572

[18] T. Minko, P. Kopečková, J. Kopeček, Comparison of the anticancer effect of free and HPMA copolymer-bound adriamycin in human ovarian carcinoma cells, Pharm. Res. 16 (1999) 986-996. 
[19] P.A. Vasey, S.B. Kaye, R. Morrison, C. Twelves, P. Wilson, R. Duncan, A.H. Thomson, L.S. Murray, T.E. Hilditch, T. Murray, S. Burtles, D. Fraier, E. Frigerio, J. Cassidy, Phase I clinical and pharmacokinetic study of PK1 (HPMA copolymer doxorubicin): first member of a new class of chemotherapeutic agents- drug-polymer conjugates, Clin. Cancer Res. 5 (1999) 83-94.

[20] P.J. Julyan, L.W. Seymour, D.R. Ferry, S. Daryani, C.M. Boivin, J. Doran, M. David, D. Anderson, C. Christodoulou, A.M. Young, S. Hesslewood, D.J. Kerr, Preliminary clinical study of the distribution of HPMA copolymers bearing doxorubicin and galactosamine, J. Control. Release 57 (1999) 281- 290.

[21] J.M. Meerum Terwogt, W.W. ten Bokkel Huinink, J.H. Schellens, M. Schot, I.A. Mandjes, M.G. Zurlo, M. Rocchetti, H. Rosing, F.J. Koopman, J.H. Beijnen, Phase I clinical and pharmacokinetic study of PNU166945, a novel water-soluble polymer-conjugated prodrug of paclitaxel, Anticancer Drugs 12 (2001) 315-323.

[22] J.M. Rademaker-Lakhai, C. Terret, S.B. Howell, C.M. Baud, R.F. De Boer, D. Pluim, J.H. Beijnen, J.H. Schellens, J.P. Droz, A Phase I and pharmacological study of the platinum polymer AP5280 given as an intravenous infusion once every 3 weeks in patients with solid tumors, Clin. Cancer Res. 10 (2004) 3386- 3395.

[23] J. Yang, K. Luo, H. Pan, P. Kopečková, J. Kopeček, Synthesis of biodegradable multiblock copolymers by click coupling of RAFT-generated heterotelechelic polyHPMA conjugates, React. Funct. Polym. 71 (2011) 294-302.

[24] K. Luo, J. Yang, P. Kopečková, J. Kopeček, Biodegradable multiblock N-(2hydroxypropyl)methacrylamide copolymers via reversible addition-fragmentation chain transfer polymerization and click chemistry, Macromolecules 44 (2011) 2481-2488.

[25] H. Pan, J. Yang, P. Kopečková, J. Kopeček, Backbone degradable multiblock N-(2hydroxypropyl)methacrylamide copolymer conjugates via reversible addition fragmentation chain transfer polymerization and thiol-ene coupling reaction, Biomacromolecules 12 (2011) 247-252.

[26] R. Zhang, J. Yang, M. Sima, Y. Zhou, J. Kopeček, Sequential combination therapy of ovarian cancer with degradable $N$-(2-hydroxypropyl)methacrylamide copolymer paclitaxel and gemcitabine conjugates, Proc. Natl. Acad. Sci. U. S. A. 111 (2014) 12181-12186.

[27] J. Yang, J. Kopeček, Polymeric biomaterials and nanomedicines, J. Drug Deliv. Sci. Technol. 30 (2015) 318-330.

[28] J. Yang, R. Zhang, D. C. Radford, J. Kopeček, FRET-trackable biodegradable HPMA copolymerepirubicin conjugates for ovarian carcinoma therapy, J. Control. Release 218 (2015) 36-44.

[29] J. Shiah, M. Dvořák, P. Kopečková, Y. Sun, C.M. Peterson, J. Kopeček, Biodistribution and antitumour efficacy of long-circulating $\mathrm{N}$-(2-hydroxypropyl)methacrylamide copolymerdoxorubicin conjugates in nude mice. Eur. J. Cancer. 37 (2001) 131-139

[30] J. Shiah, Y. Sun, C. M. Peterson, J. Kopeček, Biodistribution of free and N-(2hydroxypropyl)methacrylamide copolymer-bound mesochlorin e6 and adriamycin in nude mice bearing human ovarian carcinoma OVCAR-3 xenografts, J. Control. Release. 61 (1999) 145-157.

[31] L. W. Seymour, D. R. Ferry, D. Anderson, S. Hesslewood, P. J. Julyan, R. Poyner, J. Doran, A. M. Young, S. Burtles, D. J. Kerr, Hepatic drug targeting: Phase I evaluation of polymer-bound doxorubicin, J. Clin. Oncol. 20 (2002) 1668-1676. 
[32] T. Lammers, R. Kühnlein, M. Kissel, V. Šubr, T. Etrych, R. Pola, M. Pechar, K. Ulbrich, G. Storm, P. Huber, P. Peschke, Effect of physicochemical modification on the biodistribution and tumor accumulation of HPMA copolymers, J. Control. Release 110 (2005) 103-118.

[33] P.A. Vasey, S.B. Kaye, R. Morrison, C. Twelves, P. Wilson, R. Duncan, A.H. Thomson, L.S. Murray, T.E. Hilditch, T. Murray, S. Burtles, D. Fraier, E. Frigerio, J Cassidy, Phase I clinical and pharmacokinetic study of PK1 [N-(2-hydroxypropyl)methacrylamide copolymer doxorubicin]: First member of a new class of chemotherapeutic agents-drug-polymer conjugates, Clin. Cancer Res. 5 (1999) 83-94.

[34] B. Říhová, K. Vereš, L, Fornůsek. K. Ulbrich, J. Strohalm, V. Větvička, M. Bilej, J. Kopeček, Action of polymeric prodrugs based on $\mathrm{N}$-(2-hydroxypropyl)methacrylamide copolymers. II. Body distribution and T-cell accumulation of free and polymer-bound $\left[{ }^{125} \mathrm{I}\right]$ daunomycin, J. Control. Release 10 (1989) 37-49.

[35] D. Wang, M. Sima, R.L. Mosley, J.P. Davda, N. Tietze, S.C. Miller, P.R. Gwilt, P. Kopečková, J. Kopeček, Pharmacokinetic and biodistribution studies of a bone-targeting drug delivery system based on N-(2-hydroxypropyl)methacrylamide copolymers, Mol. Pharm. 3 (2006) 717-725.

[36] Q. Yu, C. Dong, J. Zhang, J. Shi, B. Jia, F.Wang, Z. Gan, Synthesis of poly(ethylene glycol)-bpoly $(N$-(2-hydroxypropyl)methacrylamide) block copolymers with well-defined structures and their influence on in vivo circulation and biodistribution, Polym. Chem. 5 (2014) 5617-5627.

[37] H. Pan, M. Sima, P. Kopečková, K. Wu, S. Gao, J. Liu, D. Wang, S.C. Miller, J. Kopeček, Biodistribution and pharmacokinetic studies of bone-targeting N-(2hydroxypropyl)methacrylamide copolymer-alendronate conjugates, Mol. Pharm. 5 (2008) 548558.

[38] R. Zhang, K. Luo, J. Yang, M Sima, Y Sun, M.M. Janát-Amsbury, J. Kopeček, Synthesis and evaluation of a backbone biodegradable multiblock HPMA copolymer nanocarrier for the systemic delivery of paclitaxel, J. Control. Release 166 (2013) 66-74.

[39] H. Pan, M. Sima, S.C. Miller, P. Kopečková, J. Yang, J. Kopeček, Efficiency of high molecular weight backbone degradable HPMA copolymereProstaglandin E1 conjugate in promotion of bone formation in ovariectomized rats, Biomaterials 34 (2013) 6528-6538.

[40] T. Lammers, V. Šubr, K. Ulbrich, P. Peschke, P. E. Huber, W. E. Hennink, G. Storm, Simultaneous delivery of doxorubicin and gemcitabine to tumors in vivo using prototypic polymeric drug carriers, Biomaterials 30 (2009) 3466-3475.

[41] L. Quan, F. Yuan, X. Liu, J. Huang, Y. Alnouti, D. Wang, Pharmacokinetic and biodistribution studies of $\mathrm{N}$-(2-hydroxypropyl)methacrylamide copolymer-dexamethasone conjugates in adjuvant-induced arthritis rat model, Mol. Pharmaceutics 7 (2010) 1041-1049.

[42] S. Hoffmann, L. Vystrčilová, K. Ulbrich, T. Etrych, H. Caysa, T. Müller, K. Mäder, Dual fluorescent HPMA copolymers for passive tumor targeting with $\mathrm{pH}$-sensitive drug release: Synthesis and characterization of distribution and tumor accumulation in mice by noninvasive multispectral optical imaging, Biomacromolecules 13 (2012) 652-663.

[43] P. Chytil, S. Hoffmann, L. Schindler, L. Kostka, K. Ulbrich, H. Caysa, T. Müller, K. Mäder, T. Etrych, Dual fluorescent HPMA copolymers for passive tumor targeting with $\mathrm{pH}$-sensitive drug release II: Impact of release rate on biodistribution, J. Control. Release 172 (2013) 504-512. 
[44] S. Kunjachan, F. Gremse, B. Theek, P. Koczera, R. Pola, M. Pechar, T. Etrych, K. Ulbrich, G. Storm, F. Kiessling, T. Lammers, Noninvasive optical imaging of nanomedicine biodistribution, ACS Nano 7 (2013) 252-262.

[45] Y. Mitsukami, M.S. Donovan, A.B. Lowe, C.L. McCormick, Water-soluble polymers. 81. Direct synthesis of hydrophilic styrenic-based homopolymers and block copolymers in aqueous solution via RAFT, Macromolecules 34 (2001) 2248-2256.

[46] J. Kopeček, H. Bažilová, Poly[N-(2-hydroxypropyl)methacrylamide]. 1. Radical polymerization and copolymerization, Eur. Polym. J. 9 (1973) 7-14

[47] R. Duncan, H.C. Cable, P. Rejmanová, J. Kopeček, J.B. Lloyd, Tyrosinamide residues enhance pinocytic capture of $\mathrm{N}$-(2-hydroxypropyl)methacrylamide copolymers, Biochim. Biophys. Acta 799 (1984) 1-8.

[48] J. Kopeček, P. Rejmanová, J. Strohalm, K. Ulbrich, B. Říhová, V. Chytrý, J.B. Lloyd, R. Duncan, Synthetic polymeric drugs, (1991) US Patent 5,037,883.

[49] V. Omelyanenko, P. Kopečková, C. Gentry, J.-G. Shiah, J. Kopeček, HPMA Copolymeranticancer drug-OV-TL16 antibody conjugates. 1. Influence of the methods of synthesis on binding affinity to OVCAR-3 ovarian carcinoma in vitro, J. Drug Target. 3 (1996) 357-373.

[50] B. Starcher, A ninhydrin-based assay to quantitate the total protein content of tissue samples, Anal. Biochem. 292 (2001) 125-129.

[51] C.G. Pippin, T.A. Parker, T.J. McMurry, M.W. Brechbiel, Spectrophotometric method for the determination of a bifunctional DTPA ligand in DTPA-monoclonal antibody conjugates, Bioconjugate. Chem. 3 (1992) 342-345.

[52] A. Trouet, Isolation of modified liver lysosomes, Methods Enzymol. 31(1974) 323-329

[53] P. Rejmanová, J. Pohl, M. Baudyš, V. Kostka, J. Kopeček, Polymers containing enzymatically degradable bonds. 8. Degradation of oligopeptide sequences in $\mathrm{N}-(2-$ hydroxypropyl)methacrylamide copolymers by bovine spleen cathepsin B, Makromol. Chem. 184 (1983) 2009-2020.

[54] V. Šubr, J. Kopeček, J. Pohl, M. Baudyš, V. Kostka, Cleavage of oligopeptide side-chains in N-(2hydroxypropylmethacrylamide copolymers by mixtures of lysosomal enzymes, J. Control. Release 8 (1988) 133-140.

[55] I. Schechter, A. Berger, On the size of the active site in proteases. I. Papain, Biochem. Biophys. Res. Commun. 27 (1967) 157-162.

[56] R. Duncan, P. Kopečková-Rejmanová, J. Strohalm, I. Hume, H.C. Cable, J. Pohl, J.B. Lloyd, J. Kopeček, Anticancer agents coupled to $N$-(2-hydroxypropyl)methacrylamide copolymers. I. Evaluation of daunomycin and puromycin conjugates in vitro, Br. J. Cancer 55 (1987) 165-174.

[57] S. Hasnain, T. Hirama, A. Tam, J.S. Mort, Characterization of recombinant rat cathepsin B and nonglycosylated mutants expressed in yeast. New insights into the $\mathrm{pH}$ dependence of cathepsin B-catalyzed hydrolyses, J. Biol. Chem. 267 (1992) 4713-4721.

[58] H. Kodaira, Y. Tsutsumi, Y. Yoshioka, H. Kamada, Y. Kaneda, Y. Yamamoto, S.-I. Tsunoda, T. Okamoto, Y. Mukai, H. Shibata, S. Nakagawa, T. Mayumi, The targeting of anionized polyvinylpyrrolidone to the renal system, Biomaterials 25 (2004) 4309-4315. 
[59] Q. Yu, Z. Wei, J. Shi, S. Guan, N. Du, T. Shen, H. Tang, B. Jia, F. Wang, Z. Gan, Polymerdoxorubicin conjugate micelles based on poly(ethylene glycol) and poly $(\mathrm{N}-(2-$ hydroxypropyl)methacylamide): Effect of negative charge and molecular weight on biodistribution and blood clearance, Biomacromolecules 16 (2015) 2645-2655.

[60] M.P. Borgman. T. Coleman, R.B. Kolhatkar, S. Geyser-Stoops, B.R. Line, H. Ghandehari, Tumortargeted HPMA copolymer-(RGDfK)-(CHX-A"-DTPA) conjugates show increased kidney accumulation, J. Control. Release 132 (2008) 193-199.

[61] T.A. Tran, D. Rosik, L. Abrahamsén, M. Sandström, A. Sjöberg, H. Wållberg, S. Ahlgren, A. Orlova, V. Tolmachev, Design, synthesis and biological evaluation of a mulrtifunctional HER2specific affibody molecule for molecular imaging, Eur. J. Nucl. Med. Mol. Imaging 36 (2009) 1864-1873.

[62] A. Laznickova, M. Laznicek, F. Trejtnar, H.R. Maecke, K.P. Eisenweiner, J.C. Reubi, Biodistribution of two octreotate analogs radiolabeled with indium and yttrium in rats, Anticancer Res. 30 (2010) 2177-2184.

[63] L.E. Williams, A.M. Wu, V.E. Kenanova, T. Olafsen, P.J. Yazaki, Numerical comparison of iodine-based and indium-based antibody biodistributions, Cancer Biother. Radio. 29 (2014) 9198.

[64] O. W. Press, D. Shan, J.H. Clark, J. Eary, F.R. Appelbaum, D. Matthews, D.J. King, A.M.R. Haines, P. Hamann, L. Hinman, D. Shochat, I.D. Bernstein, Comparative metabolism and retention of iodine-125, yttrium-90, and indium-III radioimmunoconjugates by cancer cells, Cancer Res. 56 (1996) 2123-2129.

[65] C.F. Foulon, P.C. Welsh, D.D. Bigner, M.R. Zalutsky, Positively charged templates for labeling internalizing antibodies: comparison of $\mathrm{N}$-succinimidyl 5-iodo-3-pyridinecarboxylate and the $\mathrm{D}$ amino acid peptide KRYRR, Nucl. Med. Biol. 28 (2001) 769-777.

[66] R.L. Araujo, D.P. Carvalho, Bioenergetic impact of tissue-specific regulation of iodothyronine deiodinases during nutritional imbalance, J. Bioenerget. Biomembr. 43 (2011) 59-65.

[67] E.B. Martin, S.J. Kennel, T. Richey, C. Wooliver, D. Osborne, A. Williams, A. Stuckey, J.S. Wall, Dynamic PET and SPECT imaging with radioiodinated, amyloid-reactive peptide $\mathrm{p5}$ in mice: A positive role for peptide dehalogenation, Peptides 60 (2014) 63-70.

[68] K. Yokoyama, J.A. Carrasquillo, A.E. Chang, D. Coicher, M. Roselli, P. Sugarbaker, W. Sindelar, J.C. Reynolds, P. Perentesis, O.A. Gansow, B. Francis, R. Adams, R. Finn, J. Schiom, S.M. Larson, Differences in biodistribution of indium-111- and iodine-131-labeled B72.3 monoclonal antibodies in patients with colorectal cancer, J. Nucl. Med. 30 (1989) 320-327.

[69] R. Cohen, D.J. Vugts, G.W.M. Visser, M.S. Walsum, M. Bolijn, M. Spiga, P. Lazzari, S. Shankar, M. Sani, M. Zanda, G.A.M.S. Dongen, Development of novel ADCs: Conjugation of tubulysin analogues to trastuzumab monitored by dual radiolabeling, Cancer Res. 74 (2014) 5700-5710. 

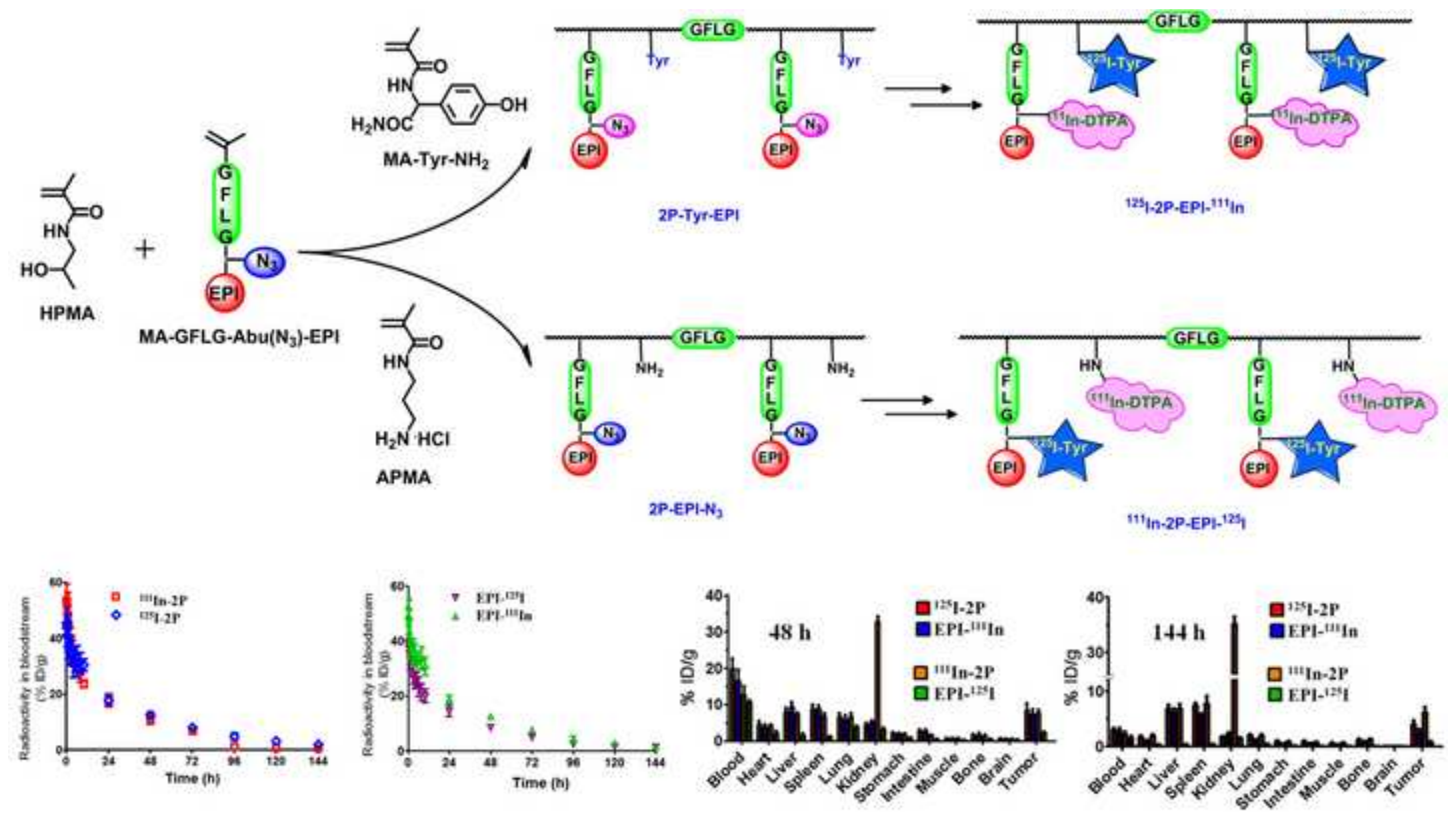